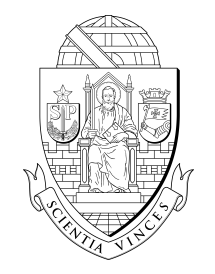

UNIVERSIDADE DE SÃO PAULO

INSTITUTO DE PSICOLOGIA

DIANA MILENA CORTÉS-PATIÑO

\title{
Efeitos do Isolamento Social
}

sobre o a Persistência na Procura em Contextos Associados ao Álcool 
UNIVERSIDADE DE SÃO PAULO

INSTITUTO DE PSICOLOGIA

\section{Efeitos do Isolamento Social}

sobre o a Persistência na Procura em Contextos Associados ao Álcool

(Versão Original)

Tese apresentada ao Instituto de Psicologia da Universidade de São Paulo como parte dos requisitos para obtenção do título de Doutor em Psicologia

Área de Concentração: Neurociências e Comportamento Orientadora: Prof. Dr. Miriam García-Mijares 
AUTORIZO A REPRODUÇÃO E DIVULGAÇÃO TOTAL OU PARCIAL DESTE TRABALHO, POR QUALQUER MEIO CONVENCIONAL OU ELETRÔNICO, PARA FINS DE ESTUDO E PESQUISA, DESDE QUE CITADA A FONTE.

\author{
Catalogação na publicação \\ Biblioteca Dante Moreira Leite \\ Instituto de Psicologia da Universidade de São Paulo
}

Cortés-Patiño, Diana Milena.

Efeitos do isolamento social sobre o a persistência na procura em contextos associados ao álcool / Diana Milena Cortés-Patiño; orientadora Miriam García Mijares. -- São Paulo, 2016.

$102 \mathrm{f}$.

Tese (Doutorado - Programa de Pós-Graduação em Psicologia. Área de Concentração: Neurociências e Comportamento) - Instituto de Psicologia da Universidade de São Paulo.

1. Isolamento social animal 2. Persistência 3. Procura 4. Álcool 5. Ratos I. Título.

QL751 
Nome: Diana Milena Cortés-Patiño

Título: Efeitos do Isolamento Social sobre o a Persistência na Procura em Contextos Associados ao Álcool

Tese apresentada ao Departamento Neurociências e Comportamento (NEC) da Universidade de São Paulo (USP) como requisito para a obtenção do título de Doutor

Aprovado em:

Banca Examinadora

Prof. Dr.

Instituição:

Assinatura:

Prof. Dr.

Instituição:

Assinatura:

Prof. Dr.

Instituição:

Assinatura:

Prof. Dr.

Instituição:

Assinatura:

Prof. Dr.

Instituição: Assinatura: 
A Emília 


\section{AGRADECIMENTOS}

Inicialmente agradeço à minha orientadora Miriam por ter me acolhido no laboratório e pela confiança depositada em mim durante todo este tempo. Obrigada por todos os aprendizados que foram muito além da psicofarmacologia. Ante todo, obrigada pelo apoio e pelo trato respeitoso e aberto que teve comigo como orientadora.

Ao Paulo, em primeiro lugar por ter sido meu professor particular de português. Obrigada pelo apoio incondicional, pela disposição continua a conversar sobre questões académicas e pela paciência quando eu já não queria conversar más. Você é um exemplo de investigador dedicado e apaixonado pelo que faz. Agradeço à vida a oportunidade de ter do meu lado uma pessoa que amo e admiro.

Cata, não tenho palavras suficientes para agradecer o quanto você fez por este trabalho. Obrigada pela ajuda com a coleta, com as discussões, com o depósito. Mais que nada, obrigada pela amizade: as conversações sobre livros e música, os pães de queijo a tarde, as corridas no final do dia. Você fez que me sentisse um pouco em casa em SP.

Aos meus colegas do Laboratório de Psicofarmacologia: Ana, Fernanda, Liane, Hernando, Yulla, Talita, Marina. Foi um prazer trabalhar com vocês. Aprendi muito no meio de pessoas com interesses e gostos tão diferentes. Vocês tornaram as brigas com a MED menos desagradáveis. Ante todo aos meus amigos Andeson e William: ver vocês sempre trabalhando me obrigava a deixar de procrastinar.

Aos meus amigos Andrés Ballesteros e Adriana Saavedra, companheiros de discussões intelectuais, pseudo-intelectuais e de muitas risadas à tarde. 
Devo agradecer também a tantas pessoas lindas que conheci no Brasil: Darlene Cardoso, Marcelo Brasil, Ariene Coelho, Saulo Velasco, Liane Dahas, Rafa Modenesi, Lucas Albim. Minha permanência no Brasil deve muitas anedotas, momentos divertidos e cervejas a vocês. Obrigada pelo carinho.

A mis amigos en Colombia Shivi, Sorecilla, Akia Miguel, Christian, Chatatan, Oscar e Tatiana. Coetzee escribió que las amistades verdaderas se basan en la admiración y esa admiración que siento por ustedes siempre ha sido un motivo para querer hacer las cosas mejor.

A mis profesores de la Universidad Nacional de Colombia Arturo Clavijo, Telmo Peña, Germán Gutiérrez y Marisol Lamprea , porque con sus enseñanzas en el pregrado y en la maestría me ayudaron a encontrar lo que me apasiona de la psicología y a decidir el camino que quería emprender.

Finalmente a mi familia. A mis papás Esneda Patiño y Gonzalo Cortés que nos enseñaron a mí y a mis hermanas, Sandra y Astrid, lo gratificante de trabajar duro y poner el alma en lo que se hace. Gracias por incentivar en nosotras la importancia de la educación. Este logro es sin lugar a duda un producto de todo el esfuerzo, dedicación y amor que pusieron en nuestra formación. 


\section{RESUMO}

Cortés-Patiño, D.M. (2016). Efeitos do Isolamento Social sobre o a Persistência na Procura em Contextos Associados ao Álcool. Tese de doutorado. Universidade de São Paulo, Instituto de Psicologia, Programa de Pós-Graduação em Neurociências e Comportamento.

Experimentos têm mostrado que ratos criados isolados consumem mais álcool durante a idade adulta que ratos criados em condições de interação social; no entanto, poucos experimentos têm explorado os efeitos do isolamento sobre a persistência na procura de álcool. A presente serie de estudos avaliou os efeitos do isolamento em etapas iniciais do desenvolvimento sobre a persistência na procura de álcool em contextos associados à sua entrega. Nos estudos, ratos foram distribuídos imediatamente depois do desmame em duas condições alojamento: isolamento (ISO) e interação (INT). Na idade adulta, os ratos foram treinados em esquemas múltiplos nos quais diferentes contextos de estímulos foram associados a diferentes taxas de entrega de álcool -magnitudes ou a reforçadores diferentes-. A persistência na procura de álcool foi avaliada como resistência à mudança em sessões de extinção. No Capítulo I foi avaliada a persistência em contextos associados a diferentes frequências de entrega de álcool. Foi achado que ratos ISO mostraram maior persistência que ratos INT em contextos associado a frequências altas e baixas de entrega de álcool. No Capítulo II foi estudado o efeito da concentração (5\% ou 15\%) de álcool sobre a persistência do comportamento de procura. Os resultados mostraram que concentrações altas de álcool geram maior persistência do comportamento de procura, embora gerem taxas baixas de resposta na linha de base. No capítulo III foram realizados dois estudos nos quais foi achado que ratos criados em isolamento persistem mais em contextos associados a concentrações altas de álcool (Experimento 3) e que o isolamento afeta particularmente a procura em contextos associados ao álcool quando comparados com contextos associados a outros reforçadores (Experimento 4). Os achados gerais demonstram que o isolamento em etapas inicias do desenvolvimento incrementa tanto o consumo quanto a persistência na procura por álcool, o que sugere que o estresse social em etapas iniciais do desenvolvimento é um fator de risco para o desenvolvimento de dependência ao álcool.

Palavras-chave: Isolamento social animal, Persistência, Procura, Álcool, Ratos. 


\begin{abstract}
Cortés-Patiño, D.M. (2016). Effects of Early Social Isolation on Persistence of Alcoholseeking in Alcohol-related Contexts.. Tese de doutorado. Universidade de São Paulo, Instituto de Psicologia, Programa de Pós-Graduação em Neurociências e Comportamento.
\end{abstract}

Several experiments have shown increased alcohol consumption in rats reared in social isolation compared to rats reared in group conditions; however, few experiments had explored the effects of social isolation on persistence of alcohol seeking. The studies presented here assessed the effects of social isolation on persistence of seeking in alcoholrelated contexts. For the studies, rats were assigned to on of two conditions after weaning: Social Isolation (ISO) or social Interaction (INT). During adulthood, rats were trained within a multiple schedule of reinforcement, in which different contextual stimuli were related to differential frequencies, magnitudes or qualities of alcohol. Persistence was assessed as resistance to extinction in extinction sessions. Chapter I measured persistence by ISO and INT rats in contexts related to high and low rates of alcohol reinforcement. It was found that ISO rats persisted more than INT rats regardless of the frequency of reinforcement. In Chapter II was studied the effect of alcohol concentration (5\% and 15\%) on persistence of alcohol seeking. Results showed that high alcohol concentrations are related to higher persistence during extinction. Chapter III presented two studies that found that ISO rats are more persistent in contexts related to high alcohol concentrations (Experiment 3), also that isolation differentially increased persistence in contexts related to alcohol compared to contexts related to other reinforcers (Experiment 4). General findings show that social isolation increase both consumption and persistence in alcohol related contexts, suggesting that social stress early in the development could be a considered a risk factor for alcohol use disorders.

Key-words: Social isolation, Persistence, Alcohol-seeking, Resistance to change, Rats 


\section{LISTA DE FIGURAS}

\section{CAPITULO 1}

\section{Artigo: Early Social isolation increases persistence of seeking in Alcohol-related}

\section{Contexts}

Figure 1. ET consumption during ET fade in and SUC fade out procedures .28

Figure 2. Baseline Dippers/min (a), ETg/kg delivered (b) and Responses/min (c)........29

Figure 3. Resistance to change during extinction sessions. .31

Figure 4. Relative persistence for rich and lean components during extinction.... .32

\section{CAPITULO 2}

\section{Artigo: Effects of Alcohol Concentration on the Persistence of Alcohol Seeking}

Figure 1. Baseline dipper deliveries per minute, alcohol delivered $(\mathrm{g} / \mathrm{kg})$, and responses

per minute.

Figure 2. Resistance to change during extinction sessions.

Figure 3. Relative response rate in the presence of the $15 \%$ context during the second extinction session.

Figure 4. Relative response rate for the $15 \%$ alcohol concentration during the concurrent schedule. 


\section{Artigo: Effects of Social Isolation on the Value of Alcohol-related Stimuli}

Figure 1. Baseline Dippers/min, Et g/kg delivered and Responses/min.

Figure 2. Resistance to change during extinction sessions.

Figure 3. Response frequency for 5\% and 15\% alcohol solutions during the concurrent schedule.

.62

Figure 4. Baseline Reinforcers/min and Responses/min for Sucrose and Alcohol...66

Figure 5. Mean amount of alcohol consumption per day $(\mathrm{g} / \mathrm{Kg})$. 67

Figure 6. Resistance to change for sucrose and alcohol during extinction sessions....68

Figure 7. Relative persistence for Alcohol and Sucrose components during

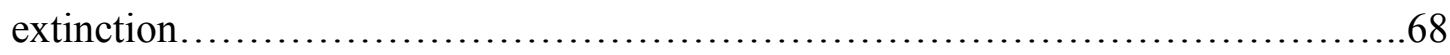




\section{SUMÁRIO}

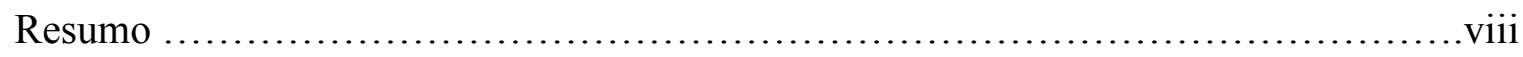

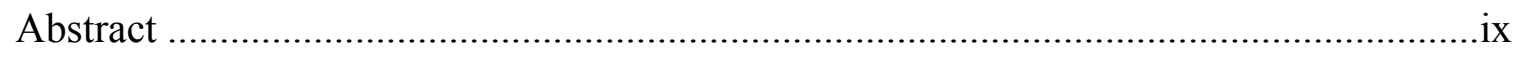

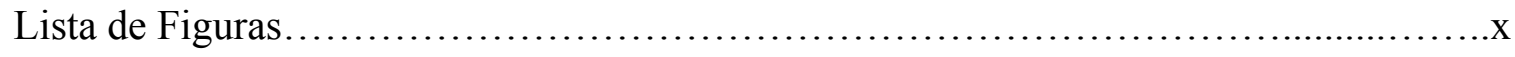

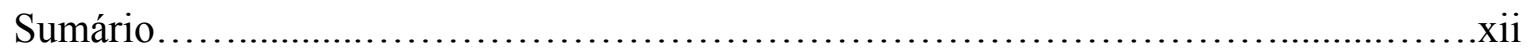

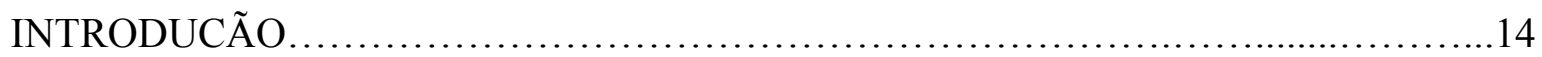

Disponibilidade de Interação Social e Consumo de álcool: Achados com

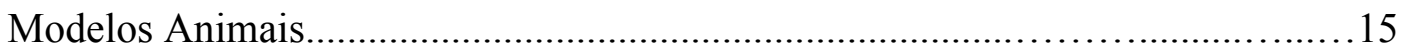

Valor Reforçador do Álcool e Interação social.................................................17

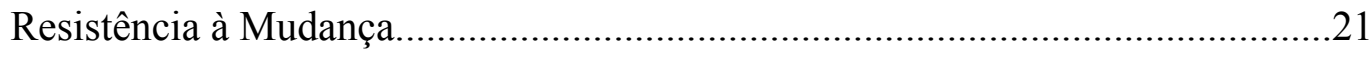

Teoria do Momento Comportamental............................................................ 24

Resistência à mudança e Álcool.......................................................................26

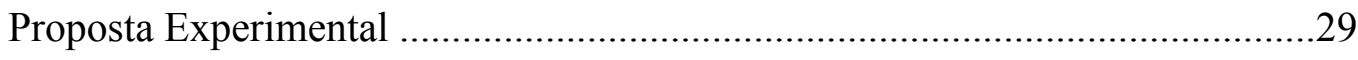

\section{CAPÍTULO 1. EFEITOS DO ISOLAMENTO SOBRE A RESISTÊNCIA À MUDANÇA}

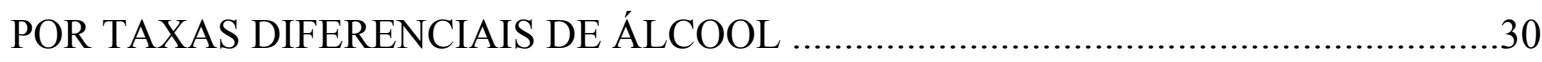

Artigo: Early Social isolation increases persistence of seeking in Alcohol-related

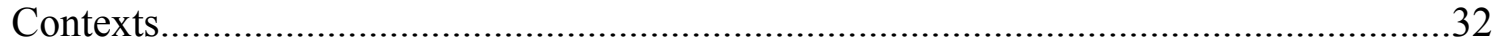

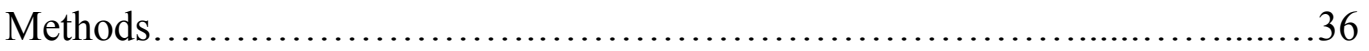

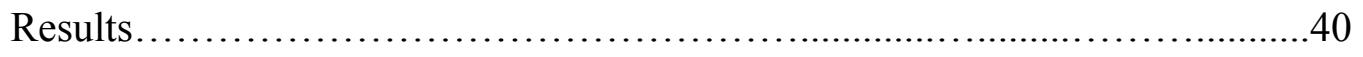

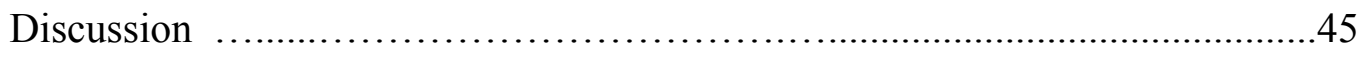




\section{CAPÍTULO 2. EFEITOS DO ISOLAMENTO EM CONTEXTOS ASSOCIADOS A} DIFERENTES DOSES E QUALIDADES DO REFORÇADOR .................................49

Artigo: Effects of Alcohol Concentration on the Persistence of Alcohol Seeking....... 51

Methods...........................................................53

Results................................................................5

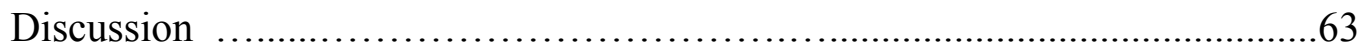

Artigo: Effects of Social Isolation on the Value of Alcohol-related Stimuli .............66

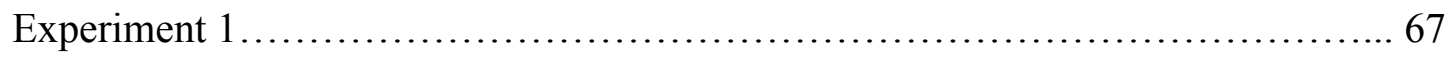

Methods............................................................68

Results............................................................... 71

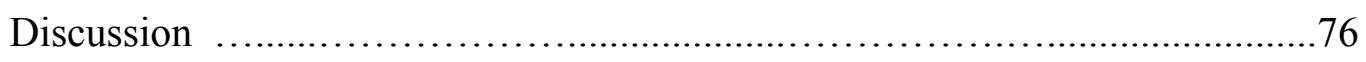

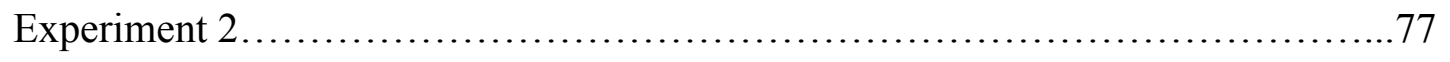

Methods............................................................ 79

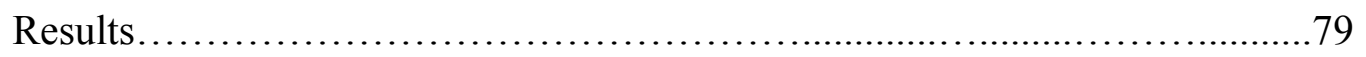

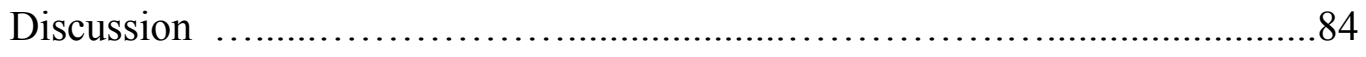

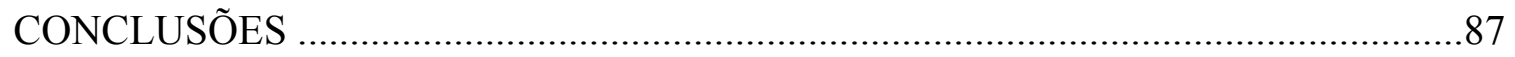

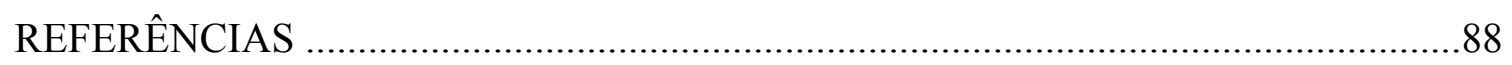


Atualmente existe um corpo de literatura extenso sobre variáveis genéticas (Files, Samson, Denning \& Marvin, 1998; Lankford, Roscoe, Pennington, \& Myers, 1991; Samson, Files, Denning, \& Marvin, 1998;) e ambientais (Heyman, 1997; Jímenez-Gómez \& Shahan, 2007; Shahan \& Burke, 2004; Turyabahika-Thyen \& Wolffgramm, 2006) que determinam o abuso de álcool. Dentre das variáveis ambientais, a disponibilidade de interação social tem recebido especial atenção, pois estudos com humanos e não humanos mostram que situações de privação social podem ocasionar incrementos no consumo (Battistich and Hom, 1997; Füllgrabe, et al., 1997; Brown and Riley, 2005; Groh et al., 2008) e determinar a aparição de fenômenos associados à dependência, como a tolerância ou a sensibilização aos efeitos do álcool após o seu uso repetido. (Araujo et. al., 2005).

A pesar da crescente literatura sobre a relação entre interação social e consumo de álcool, pouco tem sido estudado sobre a relação entre a interação social e a persistência na procura de álcool. A exploração desta última relação permitiria examinar mais profundamente o papel da interação social como um fator de proteção do abuso de álcool, que envolve comportamentos além do consumo, e que é caraterizado pela alocação excessiva de comportamento na procura de álcool em detrimento de outros reforçadores.

O objetivo da presente serie de estudos foi avaliar os efeitos da disponibilidade de interação social sobre a persistência na procura de álcool. Para fundamentar sua relevância científica, a continuação será apresentada e discutida a literatura que aborda a relação ente interação social e consumo de álcool, com ênfase nas variáveis que parecem estar relacionadas à procura de álcool. Ainda, será apresentada a resistência à mudança, dentro do marco da teoria do momento comportamental, como um índice do persistência na procura de álcool. 


\section{Disponibilidade de Interação Social e Consumo de álcool: Achados com Modelos}

\section{Animais}

Experimentos de laboratório com animais não humanos têm possibilitado avaliar os efeitos da interação social no consumo de álcool com um controle maior das variáveis envolvidas. Em estes experimentos, os sujeitos ${ }^{1}$ são criados e mantidos em condições diferenciais de alojamento (individual versus grupal). Normalmente, após a exposição às condições de alojamento durante um período de desenvolvimento crítico (pelo menos 60 dias depois do desmame), soluções com álcool são oferecidas para autoadministração e as medidas de consumo são comparadas entre as condições. A autoadministração pode acontecer dentro do alojamento, com acesso contínuo à solução, ou em contextos diferentes, com períodos de acesso restrito.

Parker e Radow (1974) avaliaram o consumo de uma solução de álcool dissolvido em água na concentração de $25 \%(\mathrm{v} / \mathrm{v})$ por ratos alojados individualmente e em pares. O consumo de álcool foi medido em sessões de 16 horas nas quais os ratos tinham acesso individual a água, álcool e comida. Depois dessas sessões, os ratos voltavam para os seus respectivos alojamentos pelas restantes oito horas do dia. Os resultados evidenciaram níveis menores de consumo nos ratos em grupo, sendo que os ratos alojados individualmente consumiam diariamente entre $10 \mathrm{~g} / \mathrm{kg}$ e $15 \mathrm{~g} / \mathrm{kg}$ e os alojados em pares consumiam entre $5 \mathrm{~g} / \mathrm{kg}$ e $10 \mathrm{~g} / \mathrm{kg}$.

Experimentos mais recentes reportaram resultados similares aos de Parker e Radow (1974), apontando que ratos com acesso à interação social consomem menos álcool que

\footnotetext{
${ }^{1}$ Pesquisas nesta área têm sido desenvolvidas com ratos, camundongos e macacos, no
} 
ratos isolados quando o álcool está disponível continuamente (Chapell, Carter, McCool, \& Weiner, 2013; Ellison, 1987; Rockman, 1989; Wolffgramm \& Heyne, 1991), durante períodos curtos de acesso (Nash, Roger \& Maickel, 1985), e inclusive quando o consumo de álcool é forçado, é dizer, quando não existem outros líquidos disponíveis para autoadministração (Thorsell, Slawecki, Khoury, Matheé, \& Ehlers, 2005).

Além do consumo absoluto, a disponibilidade de interação social afeta a preferência por álcool em relação a outras soluções. Logde e Lawrence (2003) avaliaram o consumo preferencial de álcool em ratos Fawn Hooded alojados de forma isolada ou em grupos imediatamente depois do desmame. Após nove semanas nas condições de alojamento, todos os ratos foram movidos à caixas individuais com acesso à água e a uma solução de álcool 5\%(v/v) por quatro dias consecutivos. Durante esses dias foi observado que $100 \%$ dos ratos isolados exibiram preferência (estimada como porcentagem relativa de liquido consumido) por álcool, enquanto esta porcentagem foi de $80 \%$ para os ratos em condições de interação social.

Wolffgramm e Heyne (1991) avaliaram o consumo preferencial de três doses de álcool $(5 \%, 10 \%$ e $20 \%)$ e água em ratos Wistar mantidos em três tipos de alojamento: isolamento (não era possível qualquer tipo de interação), contato (os sujeitos podiam interagir através de uma grade) e interação (os sujeitos moravam juntos e podiam interagir livremente). Comparações entre os grupos mostraram níveis maiores de consumo em ratos isolados. Adicionalmente, os ratos em condição de interação consumiram preferencialmente a dose mais baixa de álcool - quase $80 \%$ do consumo diário foi na dose de 5\% de álcool - enquanto para os ratos nas outras condições a porcentagem de preferência da mesma solução foi inferior a $40 \%$. 
Deatherage (1972) também demonstrou que ratos alojados em grupo preferem a dose menor quando forçados a consumir entre uma solução de álcool 10\% e uma solução de álcool 20\%. Da mesma forma, Hall (1998), em um estudo que avaliou a interação entre linhagem genética (com ou sem preferência por álcool) e tipo de alojamento sobre o consumo de álcool, demonstrou que independentemente da linhagem, ratos criados em isolamento consomem preferencialmente doses mais altas de álcool.

\section{Procure de álcool e Disponibilidade de Interação social}

A persistência na procura é uma das características do transtorno de abuso de álcool: indivíduos com problemas de abuso persistem na procura de álcool a pesar dos desafios impostos pelo ambiente, por isto diversos estudos têm explorado quais os determinantes da persistência de comportamentos de procura (Beardsley, Lemaire, \& Meisch, 1993).

Os estudos acima mencionados demonstraram que a disponibilidade de interação social afeta a autoadministração de álcool, no entanto, eles se focam no comportamento de consumo e não é possível determinar a partir deles se a procura por álcool é afetada pela condição social. Ao respeito, Samson, Slawecki, Sharpe, \& Chappell (1998) sugerem que no estudo da autoadministração de drogas devem-se distinguir duas etapas: a procura (etapa apetitiva) e o consumo (etapa consumatória). A procura é controlada por processos motivacionais, especificamente pelo valor reforçador da droga, enquanto o consumo é 
controlado por processos reflexos que acontecem no período pós-ingesta, como os efeitos farmacológicos ou a sensação de saciaçãoº ${ }^{2}$.

Baseados na distinção proposta por Samson et al. (1998), alguns autores tem utilizado procedimentos operantes nos quis as etapas de procura e consumo são separadas para determinar se as condições de interação social afetam a eficácia reforçadora do álcool da mesma forma que afeta o consumo. McCool e Chappell (2009) avaliaram a procura por álcool em ratos Long Evans criados em grupo ou isolados. Em um procedimento de tentativa discreta, os ratos deviam responder de acordo com um esquema de razão fixa (FR) 30 para ter acesso a um tubo com álcool $(10 \% \mathrm{v} / \mathrm{v})$ por vinte minutos, depois dos quais a sessão terminava. A procura foi avaliada como a taxa de resposta em sessões de autoadministração e em sessões de extinção. As sessões de extinção foram incluídas separadamente no meio das sessões de autoadministração, uma na terceira semana de autoadministração e outra na quinta semana. Comparações entre os grupos mostraram que a taxa de resposta por álcool durante as sessões de autoadministração foi maior nos ratos isolados do que nos ratos criados em grupo, assim, uma vez começava a sessão, os ratos isolados demoravam menos em ter acesso ao álcool. Entretanto, a procura durante as sessões de extinção não foi diferente para os dois os grupos.

\footnotetext{
${ }^{2}$ Diversos estudos têm mostrado a separação destas duas etapas. Por exemplo, Samson (1998) demonstrou que embora ratos Long Evans consumissem uma maior quantidade (ml) de uma solução com sacarose do que de álcool, a procura de ambos reforçadores, avaliada mediante esquemas de Razão Progressiva, não é diferente. Adicionalmente, Sharpe e Samson (2001) demonstraram que a injeção de Naloxone afetou o consumo de álcool, mas não a sua procura medida como a taxa de resposta em situações de autoadministração operante.
} 
Embora os resultados de McCool e Chappell (2009) pareçam indicar que a condição social afeta a procura por álcool, não é claro o porquê do efeito da interação social ter sido observado na procura nas situações de autoadministração sob o esquema FR30 e não na procura na situação de extinção. Possivelmente, o uso de um esquema de razão fixa durante as sessões de autoadministração tenha influenciado os resultados observados durante as sessões de extinção, pois estes esquemas geram uma extinção mais rápida do que outros esquemas de reforço, o que poderia ter ocasionado um efeito de piso, ofuscando qualquer diferença observável entre os grupos. Adicionalmente, a forma de apresentação das sessões de extinção (separadamente no meio das sessões de autoadministração) poderia não ter sido adequada para avaliar as diferenças na procura por álcool entre os grupos. Sessões consecutivas de extinção seriam mais apropriadas, pois permitiriam observar variações nos padrões de busca (e.g., diminuições na procura mais aceleradas ou desaceleradas) que não podem ser observados numa única sessão.

Usando um procedimento de operante livre, Deehan, Palmatier, Cain e Kiefer (2011) avaliaram os efeitos da interação social na procura por álcool em ratos de linhagens genéticas selecionadas pela sua preferência (preferring) ou rejeição (non-preferring) por álcool. Ratos das duas linhagens, recém desmamados, foram distribuídos em três grupos: isolamento, grupal e enriquecimento ambiental. Os grupos foram comparados em duas medidas de procura: a taxa de resposta durante sessões de autoadministração sob um esquema FR5 e o ponto de ruptura em esquemas de razão progressiva. Ratos da linhagem non preferring exibiram menores taxas de resposta e menores pontos de ruptura que ratos preferring. Adicionalmente, foi observado um efeito do tipo de alojamento na procura de álcool para os ratos preferring, assim, tanto a taxa de respostas sob o esquema FR5 quanto 
os pontos de ruptura foram maiores nos ratos isolados do que nos ratos em condição grupal ou de enriquecimento. Não foram observadas diferenças dependentes da condição social para ratos non preferring.

No experimento de Deehan et al (2011), o uso de ratos de linhagens com -ou sempreferencia por álcool não permite determinar se a disponibilidade de interação social afeta a procura de álcool unicamente em ratos com tendência ao consumo determinada geneticamente, ou se este efeito é encontrado também em ratos outbred - não selecionados. Adicionalmente, devido a que a taxa de resposta foi avaliada em esquemas de operante livre, o procedimento não garante a separação entre a procura e o consumo, de forma que os efeitos farmacológicos do álcool podem ter interferido na taxa de resposta nos momentos posteriores da sessão.

Mais recentemente, Lesscher et al. (2015) avaliaram os efeitos da condição social na procura por álcool utilizando esquemas de razão progressiva. Inicialmente, ratos criados isolados (ISO) e em condição social (SOC) foram avaliados no consumo de uma solução de álcool $(20 \% \mathrm{v} / \mathrm{v})$ e de agua nas gaiolas vivero. Com base no consumo médio diário de cada sujeito, ratos de ambos os grupos foram distribuídos em três categorias: Consumo Alto, Consumo Médio e Consumo Baixo. Posteriormente, foi avaliado o consumo operante de álcool (20\% v/v) em esquemas FR1 e de razão progressiva PR2 e PR4. Os resultados mostraram que embora os ratos isolados consumiram mais álcool nas gaiolas vivero, não houve diferenças entre ISO e SOC nas taxas de resposta nos esquemas operantes, pelo qual os autores sugerem que o isolamento afeta o consumo mas não a procura por álcool. Notavelmente, também não houve um efeito do nível de consumo (Alto, Médio ou Baixo) sobre as taxas de resposta. 


\section{Resistência à mudança como medida de persistência na procura}

Os estudos mencionados acima avaliaram a persistência na procura de álcool usando esquemas de razão progressiva. Embora estes esquemas tenham sido usados amplamente no estudo da persistência do comportamento (para uma revisão ver Richardson \& Roberts, 1996), este procedimento tem uma desvantagem: não permite incluir o papel do contexto de consumo na avaliação da persistência. A inclusão do contexto é fundamental quando se estuda o consumo de drogas pois tem sido mostrado que a procura de drogas é influenciada principalmente pelos estímulos associados à sua entrega. É assim que medidas como a resistência à mudança seriam mais adequadas no estudo da persistência na procura de drogas.

A resistência à mudança de um comportamento operante é estudada geralmente por meio de esquemas múltiplos de reforço. Nestes esquemas, os sujeitos são expostos a períodos alternados de dois componentes, cada um definido por um estímulo discriminativo $\left(S^{D}\right)$ diferente. Cada componente sinaliza uma condição diferencial de reforçamento; frequentemente, um dos componentes produz uma taxa maior de reforço (maior magnitude ou menor atraso) do que o outro. Os componentes estão separados por um intervalo de tempo, intervalo entre componentes (IEC), com a finalidade de diminuir a interação entre eles. Depois de um período de treino, necessário à obtenção de uma taxa de resposta estável em ambos os componentes ou linha de base (LB), um evento perturbador é introduzido e a diminuição da resposta na presença de cada $S^{D}$ é avaliada em relação à taxa de resposta durante a linha de base (Shahan \& Burke, 2004) 
Nevin (1974) avaliou como diferentes parâmetros do reforço afetam a resistência à mudança. No primeiro experimento, que examinou os efeitos da frequência de reforço na resistência à mudança, pombos deviam pressionar uma chave de acordo com um esquema múltiplo de intervalo variável (VI-VI) para ter acesso a comida. Em um dos componentes, sinalizado por uma luz verde, a comida era disponibilizada sob um esquema VI 1-min. No outro componente, sinalizado por uma luz vermelha, a comida era disponibilizada sob um esquema VI 3-min. Uma vez alcançada a estabilidade da taxa de resposta para ambos os componentes, comida não contingente à resposta foi introduzida no IEC de acordo com esquemas de tempo variável (VT) e as variações na taxa de resposta para cada componente foram registradas. Os resultados evidenciaram que a taxa de resposta diminuiu em relação à LB em ambos os componentes quando o evento perturbador (comida durante o IEC) foi introduzido; no entanto, a diminuição foi maior no componente que entregava comida com uma frequência menor (VI 3-min), ou seja, a resistência à mudança foi menor no componente com menor frequência de reforçamento, e maior no componente com maior frequência.

Nevin (1974) constatou que os efeitos da frequência reforço sobre a resistência à mudança também são observados quando a magnitude (experimento 3) ou o atraso (experimento 4) do reforço são manipulados. Assim, maiores magnitudes -ou menores demoras- de reforço geram respostas mais resistentes a eventos perturbadores.

Note-se que da mesma forma que acontece com a resistência à mudança, incrementos na magnitude, frequência e/ou imediatez do reforço geram aumentos na taxa de resposta. No entanto, Nevin, Tota, Torquato e Shull (1990) demonstraram que a resistência à mudança e a taxa de resposta não estão sempre correlacionadas e, portanto, as 
duas medidas seriam indicadores de construtos diferentes. Os autores avaliaram como a adição de reforçadores não contingentes à resposta em um dos componentes, afetava a resistência à mudança. Experimentos prévios tinham mostrado que a adição de reforçadores diminuía a taxa de resposta devido à quebra da contingência entre a resposta e o reforçador $\left(R-S^{R}\right)$. Baseados nesses achados, Nevin et al (1990) testaram se o mesmo efeito era observado quando avaliada a resistência à mudança. No Experimento 1, pombos foram expostos a um esquema múltiplo no qual o comportamento de bicar em uma chave foi reforçado com comida de acordo com o mesmo esquema nos dois componentes (e.g. VI 60s -VI 60s). Comida adicional, independente da resposta, foi entregue no componente 1 de acordo com um esquema de tempo (VT), de forma que a frequência de entrega de comida foi maior nesse componente. Depois de atingir estabilidade na taxa de resposta, extinção ou saciação com comida antes da sessão foram usados como eventos perturbadores e a resistência a mudança foi avaliada para ambos componentes. Comparações do desempenho em ambos componentes durante a linha de base mostraram que a taxa de resposta foi menor no componente que entregava comida adicional independente da resposta $(\mathrm{VT}+\mathrm{VI})$. Diferente da taxa de resposta durante a linha de base, a resistência à mudança foi maior no componente com comida não contingente à resposta. Este achado confirmou a independência entre a taxa de resposta e a resistência a mudança e levou a Nevin et al (1990) a propor um modelo que distinguisse os efeitos do reforçamento sobre a taxa de resposta e a resistência a mudança, denominado Teoria do Momento Comportamental (Behavioral Momentum Theory, BMT pela sua sigla em inglês) por analogia com o momentum na física. 


\section{Teoria do Momento Comportamental}

Na física clássica, o momentum de um corpo em movimento é o produto da massa e a velocidade. Segundo Nevin (2000), da mesma forma que a massa e a velocidade são aspectos separáveis na determinação do momentum, a taxa de resposta e a resistência à mudança são aspectos diferentes dos operantes discriminados. A taxa de resposta assintótica durante a linha de base é análoga à velocidade, e é determinada pela contingencia operante $R-S^{R}$, enquanto que a resistência à mudança, análoga à massa, é determinada pela contingência Pavloviana entre o estímulo discriminativo e o reforçador $\left(S^{D}-S^{R}\right)$. Assim, a resistência à mudança é dependente da taxa de reforço recebida num contexto de estímulos e independente da taxa de resposta durante a linha de base.

Segundo a BMT, o valor de um reforçador pode ser estimado a partir da mudança do comportamento operante na presença de um evento perturbador. Tal mudança é uma função direta da magnitude do evento perturbador e é inversamente proporcional à taxa de reforço na presença de um $S^{D}$ :

$$
\log \left(\frac{B x}{B 0}\right)=\frac{-x}{r^{a}}
$$

Na Equação 1, $B x$ é a taxa de resposta durante ou depois do evento perturbador e $B o$ é a taxa de resposta durante a linha de base. A proporção $B x / B o$ é transformada a unidades logarítmicas com a finalidade de expressar proporções iguais como diferenças iguais (Nevin \& Shahan, 2011). O termo $-x$ representa a magnitude do evento perturbador e assume valores negativos pelos efeitos de diminuição da resposta, enquanto $r$ representa a taxa de reforço na presença do estímulo discriminativo durante a linha de base. $\mathrm{O}$ 
exponente $a$ é um parâmetro livre que indica a sensibilidade do organismo à taxa de reforço (Podlesnik, 2008).

A equação 1 representa o que poderia ser denominado como resistência à mudança absoluta, ela expressa a mudança de um comportamento alvo, em relação à linha de base, quando um evento perturbador é apresentado. A pesar do seu valor heurístico, é importante notar que na Equação 1, a resistência à mudança (termo esquerdo) é adimensional pois os eventos perturbadores não podem ser expressados em unidades de reforço; por este motivo, Nevin (1992) propõe o uso de uma medida relativa de valor, isto é, a resistência à mudança relativa. Esta medida é calculada como a diferença na resistência à mudança entre dois contextos de estímulos nos quais foi aplicado o mesmo evento perturbador. Tal diferença é uma função da taxa de reforço recebida em cada um dos contextos, de acordo com a seguinte equação:

$$
\log \left(\frac{B \times 1}{B o}\right)-\log \left(\frac{B \times 2}{B 0}\right)=a \log \left(\frac{r 1}{r 2}\right)
$$

Na Equação 2, os subscritos representam os dois contextos de estímulos. Os outros termos são iguais aos descritos para a Equação 1. O parâmetro $a$ expressa a sensibilidade do organismo a variações na taxa de reforço entre os componentes, é dizer, ele representa quão sensível é o organismo à diferença entre as taxas de reforço obtidas em cada contexto (Nevin, 2002; Jiménez-Gómez \& Shahan, 2007).

$\mathrm{O}$ uso de uma medida relativa de resistência à mudança tem vantagens. Em primeiro lugar, devido a que todos os termos são convertidos em razão, não são necessárias unidades de medidas específicas referentes às respostas ou aos reforços. Em segundo lugar, devido a que o mesmo evento perturbador é aplicado em ambos contextos, os termos referentes ao 
evento perturbador se cancelam possibilitando o estudo de diferentes eventos perturbadores como saciação, extinção ou reforçamento não contingente. (Podlesnik, 2008). Por estes motivos, esta última medida tem sido a mais utilizada nos estudos de resistência à mudança.

Uma das vantagens da BMT é que, além das proposições ao respeito do valor reforçador em um contexto de estímulos, esta teoria proporciona um conjunto de equações que proveem uma estrutura quantitativa dentro da qual as variáveis que afetam a resistência à mudança podem ser representadas e comportamentos podem ser preditos a partir da manipulação dessas variáveis. De fato, Nevin \& Shahan (2011) avaliaram a adequação da BMT como modelo quantitativo, demonstrando que: a) se ajustava aos dados de resistência à mudança observados tanto em situações de laboratório, como em situações clínicas; b) modificações da equação para os diferentes tipos de eventos perturbadores (e.g., extinção, reforço não contingente, reforçamento diferencial de outros comportamentos) predizem a resistência à mudança observada em tais situações e c) o modelo prediz fenômenos conhecidos como a reinstalação e a ressurgência.

\section{Resistência à mudança e Álcool.}

Shahan e Burke (2004) estenderam a teoria de momento comportamental para o estudo do consumo e procura de álcool. Os autores avaliaram os efeitos da taxa de reforço absoluta recebida em um contexto sobre a resistência à extinção da autoadministração de álcool. Em um procedimento similar ao realizado por Nevin (1990), ratos podiam se autoadministrar álcool em um esquema múltiplo com dois componentes. Em ambos os componentes, respostas de pressão à barra eram reforçadas com álcool (10\% v/v) de acordo 
com um esquema de intervalo randômico (RI) 15-s, mas em um deles, além do álcool, comida foi entregue sob um esquema de tempo randômico (RT) 15-s, pelo qual a taxa de reforço absoluta foi maior nesse componente. A adição de comida não contingente no mesmo contexto de entrega de álcool teve dois efeitos: diminuiu a taxa de resposta por álcool durante a linha de base e aumentou a resistência à mudança do comportamento de autoadministração durante sessões de extinção. Consistente com a formulação da BMT, a resistência à extinção de comportamentos mantidos por álcool foi determinada pela relação pavloviana entre o contexto de estímulos e a taxa absoluta de reforço recebida no contexto, de forma que contextos associados com maiores taxas de reforço geraram maior resistência inclusive quando os reforçadores apresentados diferiam qualitativamente.

Corina Jímenez e Shahan (2007) avaliaram os efeitos da taxa de entrega de álcool na resistência à mudança de respostas de autoadministração. No estudo, ratos podiam se autoadministrar álcool 10\% (v/v) ao responderem sob um esquema múltiplo com dois componentes. Em um dos componentes, respostas de pressão à barra eram reforçadas de acordo com um esquema VI 15s (componente rico), no outro, respostas de pressão à barra eram reforçadas de acordo com um esquema VI 45s (componente pobre). Depois da linha de base o comportamento foi perturbado primeiro mediante extinção e depois mediante injeções de naltrexona. Consistentemente com a proposta da BMT, o comportamento de autoadministração foi mais resistente à extinção no contexto associado com uma taxa maior de entrega de álcool. A resistência aos efeitos perturbadores da naltrexona não foi afetada pela taxa de entrega de álcool durante a linha de base, é dizer, a diminuição no responder relativo à linha de base não foi diferente para os componentes rico e pobre depois das injeções de naltrexona. Os autores explicaram este resultado a partir de um efeito da 
naltrexona na sensibilidade do organismo às taxas diferenciais de reforço. Como explicado no apartado anterior, os efeitos do reforço na resistência à mudança são influenciados pela sensibilidade do organismo à diferença entre as taxas de reforço apresentadas em diferentes contextos (parâmetro $a$ na equação 2). Os efeitos farmacológicos da naltrexona teriam afetado dita sensibilidade, pelo qual o responder entre os dois componentes tornou-se indiferenciado depois das injeções.

Os resultados do estudo de Jímenez-Gómez e Shahan (2007) revelam um aspecto importante no estudo da resistência à mudança da autoadministração de álcool: além das variáveis que afetam a relação pavloviana entre o contexto de estímulos e a droga, é importante considerar quais variáveis afetam a sensibilidade do organismo ao álcool como reforçador; assim, a exploração de manipulações farmacológicas, genéticas ou ambientais que afetam o parâmetro de sensibilidade pode contribuir à compreensão da variabilidade observada no consumo e procura de álcool, quando as condições contextuais de autoadministração são mantidas constantes (Jímenez-Gómez \& Shahan, 2008). 


\section{Proposta Experimental}

Levando em conta que (1) embora a interação social tenha mostrado afetar o consumo de álcool, pouco é sabido ao respeito de como dita manipulação afeita a persistência na procura, (2) que a resistência à mudança pode ser utilizada como uma medida da persistência na procura de drogas, e (3) que o modelo de momento comportamental permite a inclusão de variáveis organísmicas e ambientais que afetam a persistência, o presente experimento pretende verificar os efeitos da disponibilidade de interação social sobre a persistência na procura de álcool medida como a resistência a mudança. Em todos os experimentos foram manipuladas as condições do reforço associadas ao álcool (e.g., taxa ou magnitude) e observados os efeitos da interação social na resistência à mudança nos contextos associados a cada condição de reforço.

A tese está dividida em três partes de acordo aos manuscritos preparados. O primer manuscrito avaliou os efeitos do isolamento social na resistência à extinção em contextos associados a taxas diferenciais de entrega de álcool. O segundo manuscrito teve como objetivo desenvolver o procedimento para avaliar o efeito da concentração de álcool na resistência a extinção. O último manuscrito apresenta dois estudos, no primeiro avaliou-se o efeito do isolamento social em contextos associados a diferentes concentrações de álcool. No segundo avalio-se o efeito do na resistência à mudança por reforçadores qualitativamente diferentes (álcool e sacarina). 


\section{CAPITULO 1}

\section{EFEITOS DO ISOLAMENTO SOBRE A RESISTÊNCIA À MUDANÇA POR TAXAS DIFERENCIAIS DE ÁLCOOL}

Artigo: Early Social isolation increases persistence of seeking in Alcoholrelated Contexts ${ }^{3}$

${ }^{3}$ O Manuscrito foi publicado no jornal Behavioural Pharmacology, Janeiro 2016. Co-autoras: Catalina Serrano e Miriam García-Mijares. 
Como mencionado, as respostas de autoadministração são mais resistentes em contextos associados com taxas altas de entrega de álcool (ricos), e menos resistentes em contextos associados com taxas baixas (pobres). Porém, essa diferença é anulada por manipulações farmacológicas que ocasionam diminuições no consumo, como é o caso da naltrexona (Jímenez-Gómez \& Shahan, 2008).

Baseados no fato de que a naltrexona - como uma manipulação farmacológica- e a interação social -como uma manipulação ambiental- têm efeitos similares sobre o consumo de álcool, o presente experimento pretende averiguar se a interação social têm um efeito similar à naltrexona quando é avaliada a resistência à mudança por álcool em contextos associados a diferentes taxas de entrega reforço. Assim, o Experimento 1 tem como objetivo avaliar os efeitos da interação social na resistência à mudança da autoadministração de álcool em contextos associados a taxas baixas e altas de entrega de álcool.

Com base nos estúdios revisados, duas hipóteses foram levantadas: (1) Devido a que condições de isolamento favorecem o consumo de álcool, hipotetizou-se que os ratos mantidos em esta condição mostrariam uma maior resistência à extinção na procura de álcool. (2) Com base nos resultados de Jímenez-Gómez e Shahan (2007) foi hipotetizado que a manipulação da interação social, de forma similar à naltrexona, poderia ocasionar uma tendência à indiferença na procura de álcool entre os contextos associados a taxas altas e baixas de entrega de álcool. 


\title{
Early Social isolation increases persistence of seeking in Alcohol-related Contexts
}

\begin{abstract}
It seems well stablished that social conditions during rearing affect adult alcohol consumption, but few experiments explored the effects of social conditions on behaviors related to alcohol dependence, as persistence of alcohol seeking. This experiment compared the effects of isolation (ISO) and interaction (INT) rearing on persistence for alcohol. Rats were trained to press a lever for a solution of $10 \%$ alcohol diluted in water; then they were exposed to a two-component multiple schedule of reinforcement (baseline). Responses in one component were reinforced by a higher rate of alcohol delivery (rich component, variable interval 15s), and responses in the other component were reinforced by a lower rate of delivery (lean component, variable interval 45s). Then, persistence of bar-pressing in the presence of each stimulus during extinction was assessed. Results from baseline showed that response rates of the rats from both groups were higher in the rich component that in the lean one, but ISO rats responded significantly more than INT rats in both components. Persistence during extinction in both components of ISO rats was also higher than INT rats . Results confirmed that social isolation increased alcohol consumption and demonstrated that it also affects other aspects of operant behavior maintained by alcohol
\end{abstract}


Persistence of drug-seeking is a central feature of substance abuse; so, several attempts have been made in order to know what biological and environmental variables could determine persistent drug-seeking behavior (Jimenez-Gomez \& Shahan, 2007). Clinical and laboratory studies indicate that context stimuli paired with drug intake affect persistence, trigger drug craving, and elicit drug- seeking responses and relapse (Bienkowski, Kostowski, \& Koros, 1999; Maccioni et al., 2007). For instance, studies with rodents using a variety of drugs like morphine, alcohol and cocaine, showed that subjects previously trained to self-administrate drugs, when presented with stimuli associated to drug intake after long periods of extinction, reinstate drug seeking behavior in the presence of drug-related stimuli, but not in the presence of unrelated stimuli (Bienkowski, Koros, Kostowski, \& Bogucka-Bonikowska, 2000; Maccioni et al., 2007). Noteworthy, drugseeking behavior in the presence of drug-related stimuli might persists during several sessions without been followed by drug and after long periods of abstinence (Weiss et al., 2001).

Persistence of drug-seeking could be explained by Behavioral Momentum Theory (BMT), as it has provided a framework to understand persistence of operant behavior and its relation with stimulus context. In general terms, BMT asserts that persistence of any behavior is the product of Pavlovian relations between environmental context in which behavior occurs and the rate, amount or quality of the reinforcers delivered in that context. Accordingly, stimulus context related to more reinforcers deliveries (higher magnitudes or a preferred quality) should produce more persistence than stimulus context related to less deliveries (lower magnitudes or less preferred) of reinforcers (Nevin, 1974, 2012). BMT also states that operant persistence in a particular context reflects the value of the reinforcer-related stimulus (Nevin \& Grace, 2000; Podlesnik, Jimenez-Gomez, \& Shahan, 
2013), thus, stimuli with higher conditioned value should produce more persistence than stimuli with less conditioned value. Taking this into account, questions about drug seeking persistence could be re-stated as questions about determinants of the value of drug-related stimuli.

Recently, some experiments had provided evidence of BMT adequacy for explaining drug seeking behavior. Jimenez-Gomez and Shahan (2007) assessed the persistence of alcohol seeking in contexts associated with differential reinforcement rates. Rats were trained to self-administer a solution of $10 \%$ alcohol a multiple schedule of reinforcement. One of the components delivered alcohol according to a RI-15s, the other component delivered alcohol according to a RI 45s. Results showed that response rates were higher during the richer component (RI- 15s). Then, extinction sessions were introduced as disruptors. Persistence was higher in presence of the stimulus related to the higher reinforcement rate. Similar results have been reported with cocaine (Quick \& Shahan, 2009), showing that value of drug-related stimuli is affected by variables as delivery frequency.

In spite of the BMT attempts to understand how environmental variables affect the value of drug-related stimuli, it is not known whether environmental variables outside selfadministration context might affect the value acquired by a drug-related stimulus. Considering environmental variables other than the context of self-administration might contribute to understand why for some individuals drug-related stimuli are more probable to induce persistence than for others.

Several studies using rodents to model alcohol self-administration have shown that social environment on early developmental stages influences alcohol consumption during adulthood. Adult rats that were isolated during rearing drink more alcohol than rats reared 
in social groups (Chappell, Carter, McCool, \& Weiner, 2013; McCool \& Chappell, 2009), and prefer alcohol to other solutions (Deehan, 2007). Furthermore, when given access to different alcohol doses, rats reared in isolation prefer the higher ones (Deehan, Palmatier, Cain, \& Kiefer, 2011; McCool \& Chappell, 2009). Some experiments have suggested that besides consumption, isolation rearing might increase alcohol seeking. When compared with socially reared rats, isolated rats exhibit higher response rates for obtaining alcohol (MacCool \& Chappell, 2013; Deehan, 2011; Deehan, 2007). Additionally, when the response requirement for obtaining alcohol is gradually increased in a progressive ratio schedule, isolated rats exhibit higher breaking points than socially enriched rats. (Deehan, 2011). Despite these findings, it is not known how isolation affects persistence in the presence of stimuli signaling availability of alcohol. Exploring this question could help answering a more general question: does social isolation affect the value of drug-related stimuli?

The purpose of the present experiment was to assess the effects of isolation on persistence of alcohol seeking in contexts signaling differential availability of alcohol. One group of rats was reared in social isolation (housed individually) and another was maintained in group during the entire experiment. Alcohol self-administration was measured in an operant procedure where response rate is separated from consumption. Persistence was measured as resistance to extinction using a multiple schedule of reinforcement (Nevin, 1974). 


\section{Methods}

\section{Subjects}

Twenty-four male Wistar rats were obtained from the Institute of Biomedical Sciences (ICB) of University of São Paulo at the age of 21 days. All rats had ad-libitum access to water and food during the growth phase (21-60 days). For the rest of the experiment, rats were maintained approx. at $90 \%$ of their weight using one hour postsession feeding. The colony room was in a $12 \mathrm{~h}$ light-dark cycle (lights on at 0800) with constant conditions of temperature and humidity.

\section{Environmental Conditions}

Right after arrival to the laboratory the rats were randomly assigned to one of two experimental conditions: Social Isolation (ISO, $n=12$ ) or Social Interaction (INT, $n=12)$. In order to ensure that all subjects experienced the rearing conditions during critic neurologic development, rats were maintained in these conditions for 60 days before the experimental phase began. Rats in INT condition were housed four per cage in ALESCO polysulfona mini-isolators ( 48 × 34 × $25 \mathrm{~cm}$ ). Rats in ISO condition were housed individually in ALESCO polysulfona mini-isolators $(37 \times 24 \times 24 \mathrm{~cm})$. Bedding was changed daily for the INT rats, and every three days for ISO rats.

\section{Apparatus}

Eight Med-Associates operant conditioning chambers (35 x 25 x 21) were used for the experiment. Each chamber was contained in a sound attenuating box with a ventilation fan. The front panel of the chamber was equipped with two response levers located $13 \mathrm{~cm}$ apart. Under each lever was located a dipper that delivered the solution and above each

lever was located a white light $(1 \mathrm{~W})$. Only the left lever was used in the experiment. Each chamber contained a $28 \mathrm{~W}$ houselight at the top of the back panel and a Sonalert $(2900 \pm 500$ 
$\mathrm{Hz}, 75-85 \mathrm{~dB})$. Experimental events were controlled in an adjacent room using Med Associates interfacing and programming.

\section{Solutions}

Solutions were prepared with 99\% ethanol, table sugar and tap water. Ethanol concentrations were calculated vol/vol (ethanol/tap water) and sucrose solutions were calculated wt/vol (sucrose/tap water). All solutions were mixed daily.

\section{Procedure}

After 60 days of rearing in the experimental conditions, rats were food deprived and underwent lever-pressing training for a solution of 10\% sucrose (SUC). This SUC solution was delivered according to a continuous reinforcement (CRF) schedule for two consecutive days, and then deliveries were made according to a variable-ratio (VR) schedule of reinforcement in order to generate higher response rates. The VR schedule was gradually increased from VR5 to VR10 across four sessions. SUC consumption was assessed during seven days using a VR10 schedule. The same schedule of reinforcement was used during the entire ethanol (ET) self -administration training.

ET self-administration training was conducted with a modified sucrose fading procedure (Samson, 1986). In the first part of the procedure, fade in, SUC concentration was kept at $10 \%$ while ET concentration increased. Solutions were presented as follows: $10 \% \mathrm{SUC}-2.5 \% \mathrm{ET}^{4}$ for four sessions, $10 \% \mathrm{SUC}-5 \% \mathrm{ET}$ for four sessions, and $10 \% \mathrm{SUC}$ $-10 \%$ ET for five sessions. In the second part of the procedure, fade out, SUC concentration in the solution waned and ET was kept constant. Solutions were presented as follows: $7.5 \% \mathrm{SUC}-10 \% \mathrm{ET}$ for three sessions, $5 \% \mathrm{SUC}-10 \% \mathrm{ET}$ for four sessions, $2.5 \%$

\footnotetext{
${ }^{4}$ The percentage represents the concentration of the solute (sucrose-SUC or ethanol-ET)
} 
SUC $-10 \mathrm{ET} \%$ for four sessions, and finally, $0.25 \%$ SUC $-10 \%$ ET for eight sessions. This latter solution $(0.25 \%$ SUC - $10 \%$ ET) was used during the remaining sessions of the experiment. All sessions in this phase ended after 30 minutes.

After completing self-administration training, alcohol was delivered according to VI $15 \mathrm{~s}$ schedule. VI values were selected without replacement from a 10 intervals list constructed according to the Fleshler and Hoffman (1962) progression. Once responding on VI 15s schedule was steady, a multiple schedule with two components arranging differential alcohol reinforcement rates was introduced (see Jimenez-Gomez and Shahan, 2007). In the multiple schedule, one of the components was signalized by a steady tone and houselight, the other by a blinking houselight and a pulsing tone ( $0.5 \mathrm{~s}$ on, $0.5 \mathrm{~s}$ off). Initially, responding in both components was reinforced according to a VI $15 \mathrm{~s}$ schedule, but for one of the components, VI value increased gradually across the sessions until it reached VI 45s. The final multiple schedule used in the baseline phase consisted of a VI 15s component (rich component, 4 dippers/min) and a VI 45s component (lean component, $1.33 \mathrm{dippers} / \mathrm{min}$ ). Stimuli associated to rich and lean components were counterbalanced across subjects.

Baseline sessions began with a $15 \mathrm{~min}$ blackout, then first component was selected with a $\mathrm{p}=0.5$. Components alternated during session and were separated by a 30 s intercomponent interval during which all stimuli in the box were turned off, and responding have no programmed consequences. Components were 60s long and sessions ended when each component appeared ten times.

Extinction sessions began after response rate stability on the multiple schedule (i.e five consecutive sessions without trend as determined by visual inspection, between 42 and 78 days across subjects). On extinction sessions, components were presented as in the 
baseline sessions, however, responding has no programmed consequences. Compound stimuli were presented and the solution was placed outside the chamber, however, the dipper did not lift.

\section{Data Analyisis}

Ethanol consumption ( $\mathrm{g} / \mathrm{kg}$ per session) during the self-administration training was examined using two-factor mixed analysis of variance (mixed ANOVA), with rearing as between subjects factor and session as repeated measure. Since main effects and interactions involving the session variable were non-significant, data were grouped across sessions in order to simplify the analysis.

For baseline, measures of consumption ( $\mathrm{g} / \mathrm{kg}$ per session), reinforcement rate and response rate were obtained for each component. Response and reinforcer rates were measured as the number of lever presses and dipper presentations, respectively, per minute of time spent in each component during the entire session. Mixed ANOVA was performed to analyze the data of this phase, using rich and lean components as within-subjects factor and rearing as a between-subject factor.

Resistance to extinction was calculated as the log proportion of response rate during extinction relative to baseline response rate. In order to do this calculation, response rate for each extinction session was divided by the average response rate during baseline, obtained from the last five days before disruption, and then transformed to logarithmic units. Log proportions of baseline are the most used measure of resistance to change because it allows the examination of functional relation without distortion by floor effects; additionally, logarithms render equal proportional changes in equal differences (Nevin and Grace, 2000). Statistical analyses of resistance to extinction were conducted by similar mixed ANOVA 
performed during baseline, but with session of extinction added as a second within subject variable.

An additional analysis measured persistence as relative resistance to change. Nevin (2000) defined relative resistence to change as the difference in persistence between two or more components. This measure allows determining the difference in the value of two stimulus context: the more the difference between components, the more the difference in value between the components. Relative resistance to change was calculated by subtracting resistance to extinction in the lean component (proportion of baseline responding in the lean component) from the resistance to extinction in the rich component (proportion of baseline responding in the rich component). The higher the value of relative resistance to change, the bigger the difference in persistence between the two components. Lower or zero values indicate indifference in the persistence between the components.

For all analysis, effect sizes were computed using $\eta^{2}$, and statistical significance was determined using as criterion $\mathrm{p}<.05$.

\section{Results}

\section{Acquisition (ET Fade in -SUC Fade Out)}

Rearing condition did not affect sucrose intake during initial training $(p>.05$, data not showed). As depicted in Figure 1, there were no significant differences in ET consumption between ISO and INT rats during the ET fade in procedure, when sucrose was constant at $10 \%$. However, during SUC fade out, ISO rats drank more alcohol than INT rats. The effect of rearing was significant when the SUC concentration was $2,5 \%$ and $0,25 \%, F \mathrm{~S}>8.6, p<$ $.05, \eta^{2}=0.18$ and 0.28 respectively. No interaction between rearing and session was found. 

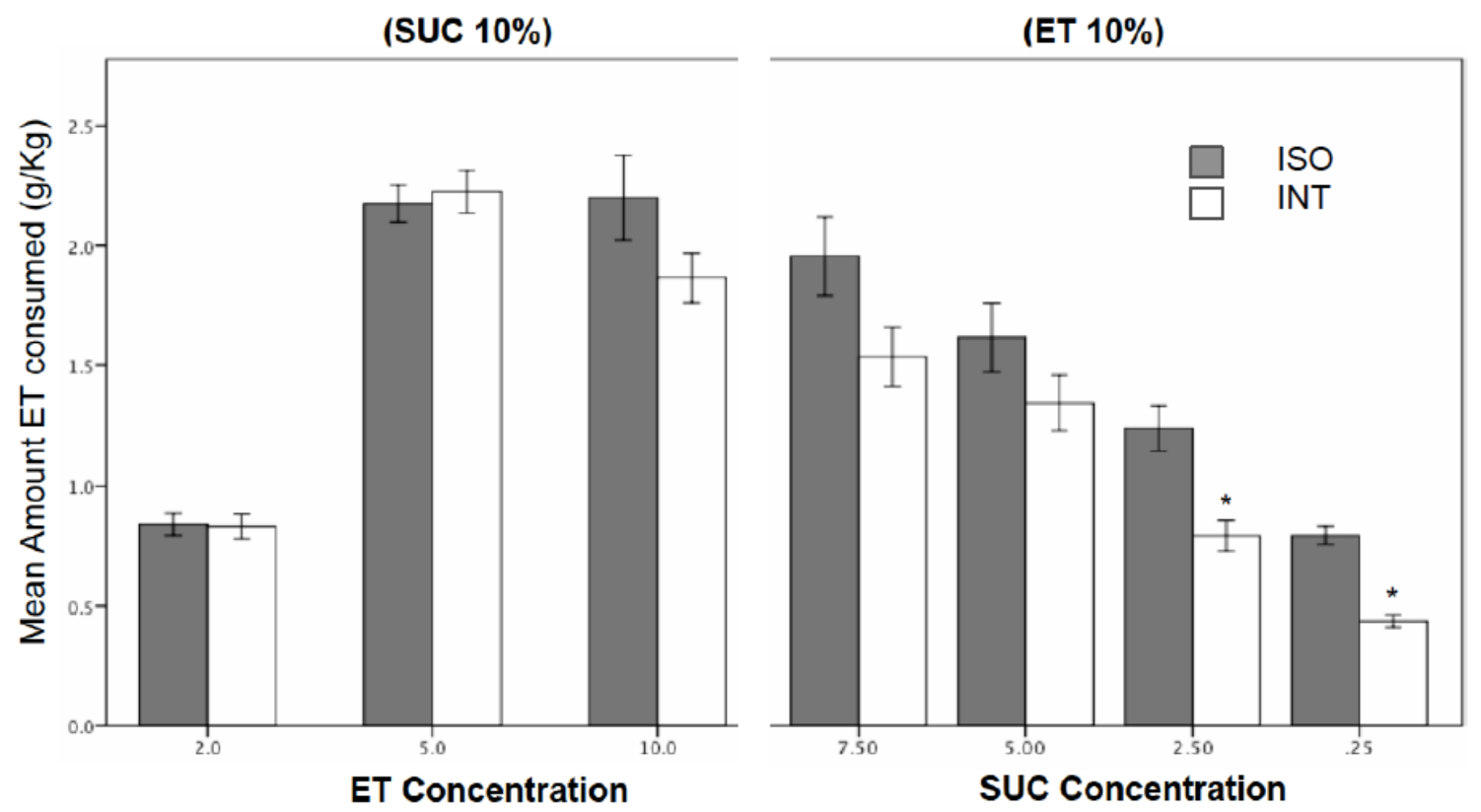

Figure 1. ET consumption during ET fade in (left panel) and SUC fade out (right panel) procedures. During the ET fade in procedure SUC concentration was fixed at $10 \%$, and ET concentration varied. During SUC fade out procedure ET concentration was fixed at $10 \%$ and SUC concentration varied. Dark bars represent ISO group, and light bars represent INT group. Asterisks indicate significant differences in ET consumption between ISO and INT $(\mathrm{p}<.05)$.

\section{Baseline}

Top panel of Figure 2 shows mean of reinforcer deliveries (dipper deliveries) of the last five sessions before extinction. For ISO and INT rats, dipper deliveries were higher in the rich component (dark bars) $\left[F=555.056, p<.001, \eta^{2}=0.962\right]$, but ISO rats (left side of the graph) obtained more alcohol deliveries from rich and lean components $[F=6.4, p<$ $\left..02, \eta^{2}=0.22\right]$. There were no interaction between theses variables. 


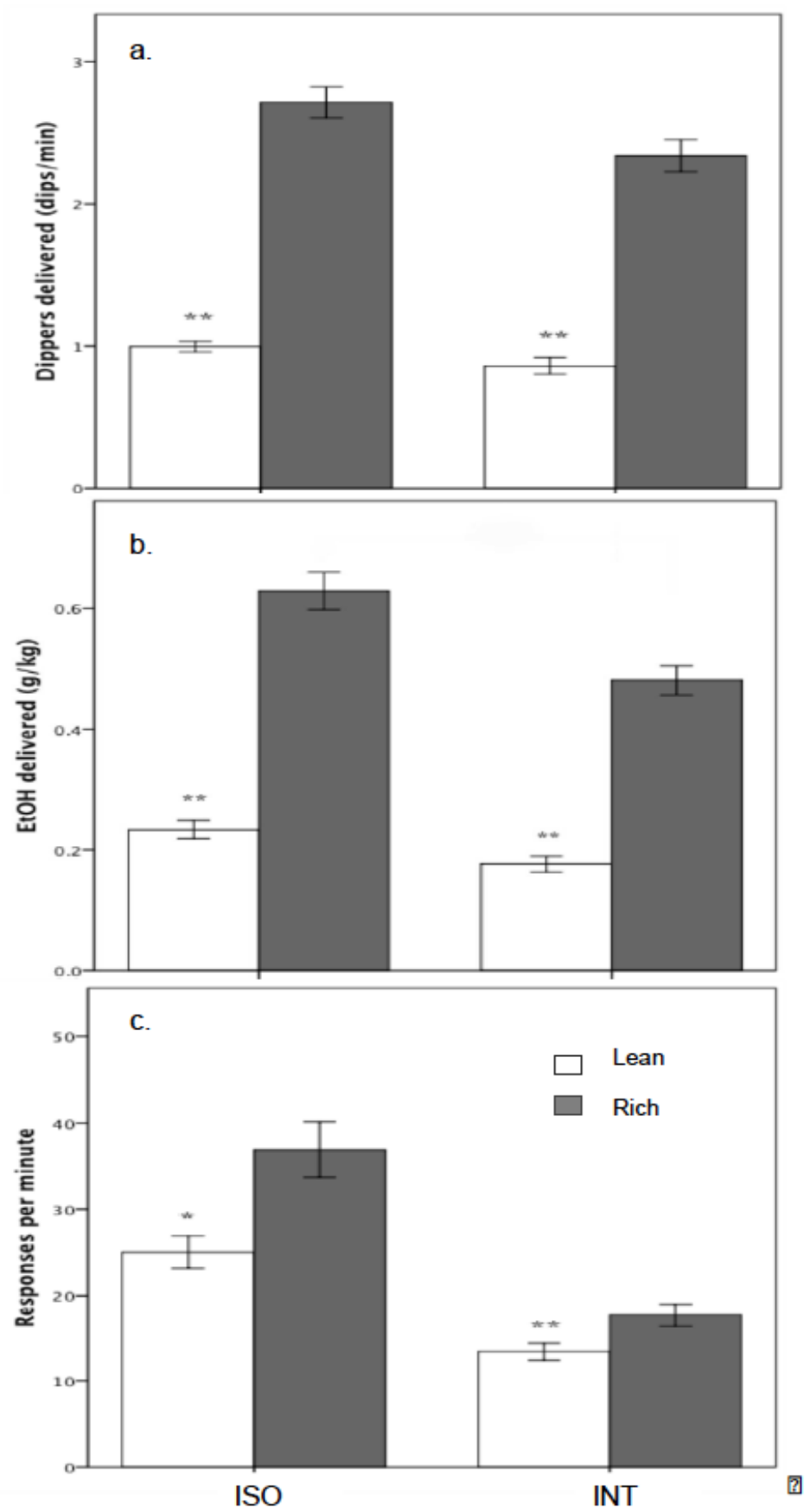

Figure 2. Baseline Dippers/min (a), ETg/kg delivered (b) and Responses/min (c). Data correspond to the last five sessions of baseline. Dark bars represent the rich component, and light bars represent the lean component. Asterisks represent significant differences $(* \mathrm{p}$ $<.05 ; * * \mathrm{p}<0.01)$ 
Analysis of average dipper deliveries for both groups showed that obtained reinforcer rates were lower than the programmed reinforcer rates $(1.33$ for the lean component, and 4 for the rich component). ISO rats mean reinforcer rates for lean and rich components were 0.9 and 2.7, respectively. INT rats mean reinforcer rates for lean and rich components were 0.8 and 2.3, respectively. Nevertheless, the programmed ratio (1:3) was maintained. Alcohol consumption $(\mathrm{g} / \mathrm{Kg})$ was also affected by rearing conditions (middle panel of Figure 2). ISO rats consumed significantly more alcohol from both rich and lean components $\left[F=14.068, p<.005, \eta^{2}=0.39\right]$. As expected, both groups consumed more alcohol from the rich component $[F=581.45, p<0.001, \eta 2=0.95]$. Additionally, the interaction between factors was significant; suggesting that the difference in $\mathrm{g} / \mathrm{kg}$ obtained from rich and lean components was bigger for the ISO group $[F=10.158, p<.005$, $\eta 2=0.31]$

Bottom panel in Figure 2 shows response rate per minute for the last five sessions preceding extinction. Both groups emitted higher response rates in the rich component $[\mathrm{F}=18.34, \mathrm{p}<0.001, \eta 2=0.45]$, but ISO group had higher overall response rate $[F=6.156, p<.05, \eta 2=0.21]$. The interaction term was not statistically significant.

\section{Extinction}

Persistence during extinction is showed in Figure 3. Greater persistence is evidenced by a higher log proportion of baseline responding during the extinction sessions. For both groups, response rate during extinction diminished as sessions advanced $(F=66.31 p<.001$ $\eta 2=0.86$ ). Additionally, proportion of baseline responding was higher in the rich component for both groups $(F=17.94 \mathrm{p}<.001, \eta 2=0.44)$. The interaction term between component and session was not significant. 
As depicted in Figure 3, persistence was affected by rearing conditions. ISO rats exhibited higher resistance to extinction than INT rats in both components $(F=4.69 p<.05$, $\eta 2=0.17)$. Difference in persistence between the rich and lean components was not affected by rearing conditions as shown by comparisons of relative resistance to change between groups $(p>.05$, Figure 4$)$.
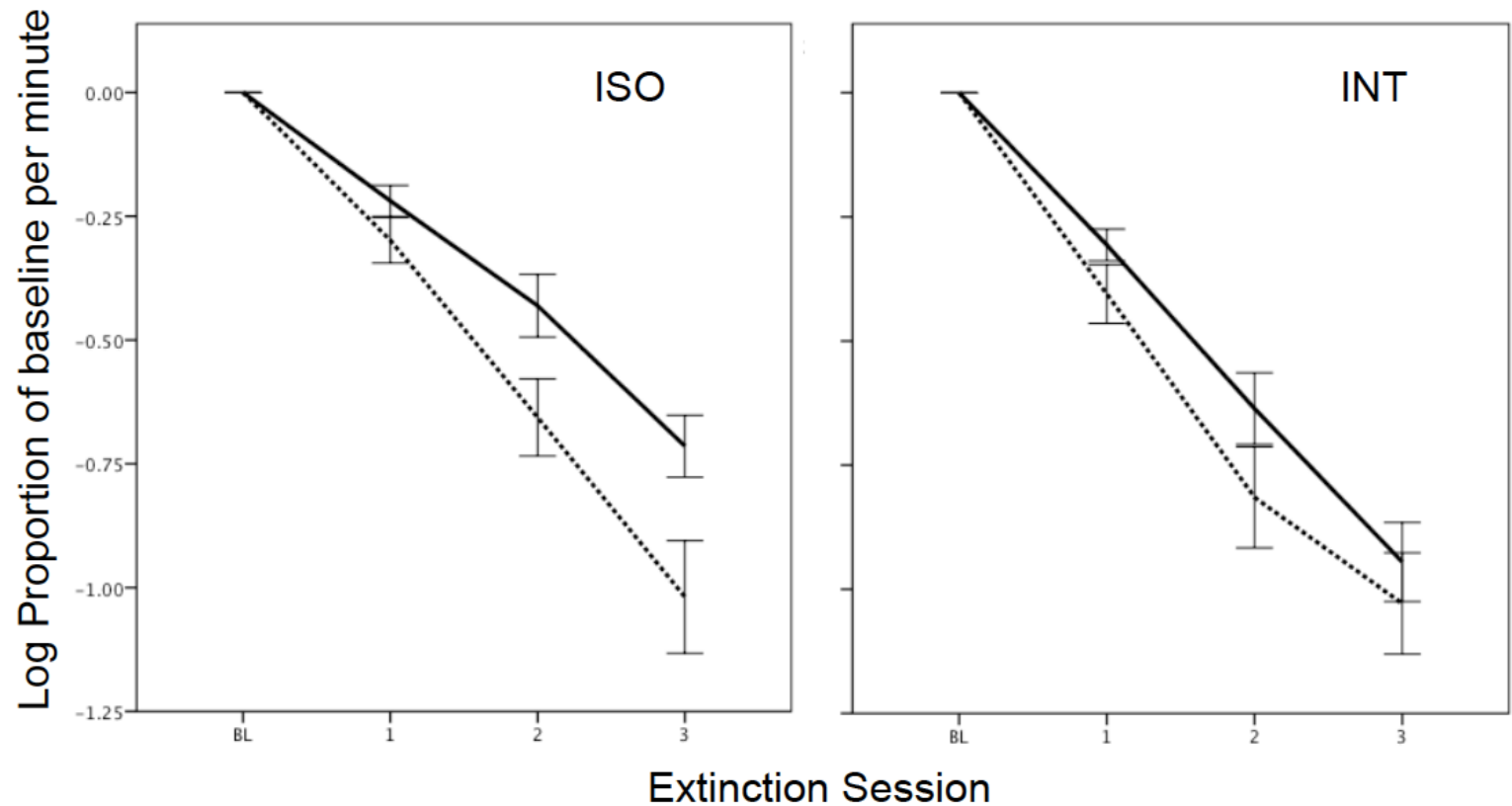

Figure 3. Resistance to change during extinction sessions. Log proportion of baseline responses per minute are presented for ISO and INT groups. Filled lines represent responding in the rich component, and dotted lines represent responding in the lean component 


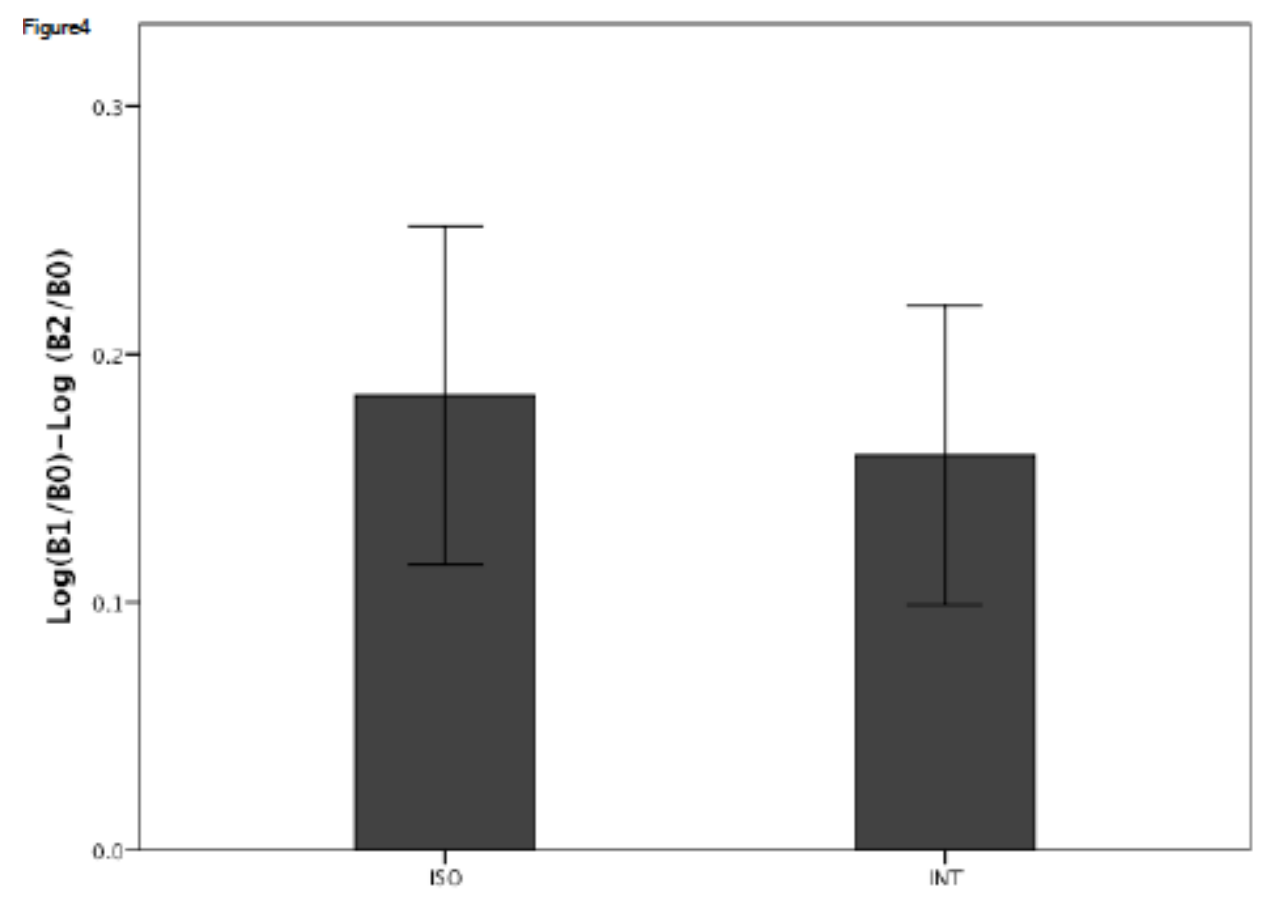

Figure 4. Relative persistence for rich and lean components during extinction. Data were analyzed by subtracting the log proportion of the baseline responding in the lean component (B2/B0) from the log proportion of baseline responding in the rich component (B1/B0).

\section{Discussion}

Social conditions during early stages of development have shown to affect several behaviors that might increase vulnerability to drug abuse (Araujo et al., 2005; Hall, Huang, Fong, Pert, \& Linnoila, 1998b; Jochen Wolffgramm \& Heyne, 1995). The present study assessed if social conditions affecting alcohol self-administration could also affect persistence when alcohol is no more available. Our results indicated that early isolation increased alcohol consumption and responding, , as well as the persistence of seeking, in the presence of drug related stimuli.

Differences in alcohol consumption by rats reared in isolation (ISO) and group (INT) conditions were observed early in the experiment and lasted for the entire study. During the 
fading procedure, initial sucrose consumption was not different between groups, but as alcohol concentration increased, consumption by ISO rats was higher than consumption by INT rats. This difference was significant at the lower sucrose concentrations, when INT rats drastically decreased their alcohol consumption. During baseline, in which alcohol was delivered in two different contexts (rich and lean), ISO rats continue to exhibit a higher response rate for alcohol regardless of the component. Furthermore, since sucrose consumption was not affected by rearing conditions, it seems that isolation effects were specific for alcohol. Our results are similar to others reported by studies using operant models, showing that isolated reared rats exhibit higher response rates for alcohol in continuous (McCool \& Chappell, 2009) and intermittent schedules of reinforcement (Deehan, Cain, \& Kiefer, 2007; Deehan, Palmatier, Cain, \& Kiefer, 2011a).

Resistance to extinction analysis showed that ISO rats were more persistent in alcohol related contexts than INT rats. Recently, Whitaker, Degoulet, and Morikawa (2013) reported similar results using a different experimental paradigm. The authors demonstrated that the rate of learning about alcohol-related stimulus in a conditioned place preference (CPP) was faster in isolated reared rats than goups reared rats. Isolated rats were also more persistent in alcohol seeking during CPP extinction than group reared rats. Taken together, both experiments results suggest that persistence of alcohol seeking is affected by isolation rearing.

Persistence of seeking behavior was higher in the rich context and lower in the lean context for ISO and INT groups, in other words, relative persistence was not affected by rearing conditions. Different from these results, there is data suggesting that relative persistence of alcohol seeking is affected by some pharmacological conditions decreasing 
alcohol consumption. For example, using a similar procedure, Jímenez-Gómez and Shahan (2007) assessed the effects of naltrexone (an opiod anthagonist that have shown to decrease alcohol consumption) on persistence in contexts associated with different alcohol delivery rates. Results showed that before naltrexone injections, response rates were higher in the richer component, but after naltrexone injections response rates were similar for the rich and the lean components. So, naltrexone affected relative resistance to extinction. Authors explained this result as an effect of naltrexone on the sensitivity to the organism to different rates of reinforcement.

The differences between our results and those obtained using naltrexone suggests that although both manipulations, social interaction and naltrexone injections, are related with decrements in alcohol consumption, mechanism by which social isolation and naltrexone decrease alcohol consumption and seeking might be different. Further experiments could explore differences in relative resistance to change when qualitatively distinct reinforcers are delivered in each context. That could help to understand how the value of alcohol, relative to another reinforcer, is affected by isolation.

In conclusion, results of the present experiment confirmed previous findings suggesting that early social isolation increases alcohol consumption, and responding for alcohol. Additionally, this study supports the idea that social isolation also increases persistence in the presence of alcohol related stimuli. If as proposed by BMT, persistence is a measure of the conditioned value of a stimulus, we could argue that the value of alcoholrelated stimuli is increased by early isolation. 
Further studies could identify which mechanisms are implicated in the increasing alcohol seeking produce by early isolation. There is, however, data in the literature that suggest that changes in synaptic plasticity in dopaminergic areas might be the mechanism through which early isolation affects alcohol seeking. The dopaminergic system originating in the Ventral Tegmental Area (VTA) plays an important role in learning about which environmental stimuli lead to reward (Schultz, 2010, 2013). Increases in synaptic plasticity in the VTA system, resulting from repetitive exposure to drugs, are responsible for the formation of enduring memories about drug-related stimuli (Everitt et al., 2008; Hyman, Malenka, \& Nestler, 2006). Whitaker et al. (2013) showed that isolation during adolescence has a similar effect to the repetitive exposure to drugs: it enhances long-term potentiation (LTP) of NMDAR-mediated glutamatergic transmission in the dopaminergic neurons of the. This neuro-physiological changes would explain the effects of isolation on learning about reinforcer related stimuli reported in some studies with drugs (Kennedy, Panksepp, Runckel, \& Lahvis, 2012; Zakharova, Miller, Unterwald, Wade, \& Izenwasser, 2009) and sucrose (Harmer \& Phillips, 1998; Van Den Berg et al., 1999). Nevertheless, there is need for more studies exploring the relation between the physiological and behavioral effects of early in order to understand how social conditions affect processes linked to drug addiction. 
CAPITULO II:

EFEITOS DO ISOLAMENTO NA PROCURA DE 'ALCOOL EM

CONTEXTOS ASSOCIADOS A DIFERENTES DOSES E QUALIDADES DO REFORÇADOR

Artigo 1: Effects of Alcohol Concentration on the Persistence of Alcohol Seeking ${ }^{5}$ Artigo 2: Effects of Social Isolation on the Value of Alcohol-related Stimuli ${ }^{6}$

${ }^{5}$ Manuscrito preparado para publicação. Co-autores: Andy Craig, Miriam García-Mijares, Timothy Shahan.

${ }^{6}$ Manuscrito preparado para publicação. Co-autores: Catalina Serrano e Miriam García-Mijares. 
Os resultados do primeiro experimento demonstraram que o isolamento em etapas iniciais do desenvolvimento incrementa a persistência em contextos relacionados com álcool, independentemente da frequência de entrega de álcool nesses contextos; no entanto, não é conhecido se a condição de isolamento afeta diferencialmente a procura por álcool quando características do contexto diferentes à frequência de entrega do reforçador, como a magnitude ou a qualidade do reforçador- são manipuladas. Levando o anterior em consideração, o objetivo do segundo capítulo é abordar os efeitos do isolamento na procura por álcool em contextos associados a (1) diferentes concentrações (i.e., doses) de álcool, e (2) diferentes qualidades de reforçador (i.e., álcool versus sacarose).

O capítulo está composto por dois artigos experimentais. O primeiro artigo "Effects of Alcohol Concentration on the Persistence of Alcohol Seeking” teve como objetivo desenvolver um procedimento para avaliar os efeitos da dose de álcool tanto na resistência à mudança quanto na preferencia pelas doses de álcool. O segundo "Effects of Social Isolation on the Value of Alcohol-related Stimuli" consta de dois experimentos, O primeiro experimento avaliou os efeitos do isolamento sobre resistência à extinção por diferentes doses de álcool e sobre a preferencia por estímulos associados a cada dose. No segundo experimento foi avaliado o efeito do isolamento na resistência à extinção por reforçadores qualitativamente diferentes (álcool e sacarose) 


\section{Effects of Alcohol Concentration on the Persistence of Alcohol Seeking}

Contextual stimuli that are related to drug self-administration have been shown to be determining factors in the persistence of drug seeking and relapse (Bienkowski, Koros, Kostowski, \& Bogucka-Bonikowska, 2000; Bienkowski, Kostowski, \& Koros, 1999). Several studies with rodents have shown that exposure to stimuli that are previously associated with alcohol consumption increases the likelihood of alcohol-seeking behavior and induces the reinstatement of alcohol seeking after long periods of extinction (Maccioni et al., 2007; Shahan \& Jimenez-Gomez, 2006; Whitaker, Degoulet, \& Morikawa, 2013)

Behavioral Momentum Theory (BMT) has provided insights into the ways in which the context in which drugs are consumed can affect the persistence of behavior (Pyszczynski \& Shahan, 2011; Shahan \& Burke, 2004). According to BMT, there are two distinct aspects of behavior: response rate and resistance to change (i.e., persistence). The relationship between the operant response and its consequences determines the response rate. The Pavlovian relationship between the context in which behavior occurs and the rate or magnitude of the reinforcer determines persistence. The independence of these two aspects is supported by studies in which the addition of response-independent reinforcers decreased the response rate as a result of degradation of the operant contingency but increased resistance to change as a result of enhancing the Pavlovian contingency (Nevin \& Grace, 2000).

As proposed by BMT, manipulations of the Pavlovian stimulus-reinforcer relationship have been shown to affect the persistence of alcohol seeking. For example, contexts that are related to high frequencies of alcohol deliveries produce a greater persistence of alcohol seeking than contexts that are related to low frequencies of alcohol 
deliveries (Jimenez-Gomez \& Shahan, 2007). Additionally, the persistence of alcohol seeking has been shown to occur independently of responding, in which the addition of non-drug reinforcers in an alcohol-related context decreased responding for alcohol during baseline but increased the persistence of alcohol seeking in the same context when alcohol was unavailable (Pyszczynski \& Shahan, 2011).

Experiments that have been based on BMT to understand the persistence of alcohol seeking have focused primarily on the effects of manipulating the frequency of reinforcement (Jimenez-Gomez \& Shahan, 2007; Pyszczynski \& Shahan, 2011; Shahan \& Burke, 2004). Other sources of manipulations of the Pavlovian stimulus-reinforcer relationship (e.g., the magnitude or quality of reinforcement) have been relatively poorly studied. Examinations of the effects of alcohol magnitude (i.e., alcohol concentration) on the persistence of alcohol seeking are important because, unlike the effects of frequency, the effects of alcohol concentrations on alcohol seeking are not linear.

Studies with rodents have shown that increasing the alcohol concentration has a bitonic effect on alcohol-seeking behavior. Rats exhibit low response rates for low doses, higher response rates for moderate doses, and lower response rates for high doses (Elmer, Meisch, \& George, 1987; Meisch \& Thompson, 1974; Slawecki \& Samson, 1997). Notably, Shahan and Jimenez-Gomez (2006) showed that this pattern is also found in an observing-response procedure that assesses responding that is maintained by alcoholrelated cues. Rats were exposed to a mixed schedule of reinforcement, in which lever responses were followed either by the delivery of a specific alcohol concentration or by extinction. Responses on a different lever (i.e., observing responses) could produce stimuli that were related to the alcohol $\mathrm{S}^{+}$or extinction $\mathrm{S}^{-}$. The observing response did not alter the availability of alcohol; it only produced contact with stimuli that were related to either the 
reinforcer or extinction. The results showed that observing responses followed an inverted U-shaped.

The bitonic function that is observed between the alcohol concentration and alcohol seeking has been suggested to result from the titration of alcohol consumption because of the satiation that is produced by high alcohol doses (Slawecki \& Samson, 1997). An alternative explanation may be preference for low to medium alcohol concentrations because of aversion to the taste of alcohol. Rats tend to prefer low alcohol concentrations in choice situations (Hall, Huang, Fong, Pert, \& Linnoila, 1998a).

Unknown is whether dose-dependent changes in responding and preference would also be observed when persistence is assessed in the absence of alcohol or whether (according to BMT) the persistence of alcohol seeking increases in contexts that are related to higher alcohol concentrations. The present study had two goals. First, we assessed the persistence of alcohol seeking in the presence of stimuli that signaled two alcohol concentrations (5\% and $15 \%, \mathrm{v} / \mathrm{v})$ using a multiple schedule of reinforcement. Second, we assessed whether the alcohol concentration affects preference either for the alcohol solution or for the stimulus that is associated with the alcohol solution. We sought to determine whether preference that is observed in response to a specific alcohol concentration is related to the persistence of alcohol seeking.

\section{Methods}

\section{Subjects}

Eight Long Evan rats, approximately 120 days old, were obtained from Charles Rivers Laboratories (Portage, MI, USA) and maintained at $80 \%$ of their adult weight by post-session feeding. The rats were singly housed in a temperature-controlled colony with a $12 \mathrm{~h} / 12 \mathrm{~h}$ light/dark cycle (lights on at $7 \mathrm{AM}$ ). All of the rats had free access to water in the 
homecage. Only five of the rats were used in the experiment because three of them did not drink pharmacologically active doses of alcohol.

\section{Apparatus}

Four Med-Associates operant conditioning chambers $(35 \mathrm{~cm} \times 25 \mathrm{~cm} \times 21 \mathrm{~cm})$ were used in the experiment. Each chamber was placed in a sound-attenuating box with a ventilation fan. The front panel of the chamber was equipped with two response levers that were located $13 \mathrm{~cm}$ apart. Above each lever was a white light $(1 \mathrm{~W})$. In front of each lever (on the back panel) were two solenoid-operated dippers that delivered the solutions. Each chamber contained a $28 \mathrm{~W}$ houselight at the top of the back panel. During dipper presentations, the white lights and houselight were turned off. Experimental events were controlled in an adjacent room using a Med Associates interface and program.

\section{Solutions}

The solutions were prepared with $95 \%$ ethanol, table sugar, and distilled water. The ethanol concentrations were calculated as $\mathrm{v} / \mathrm{v}$ (ethanol/water), and sucrose solutions were calculated as w/v (sucrose/water). All of the solutions were mixed approximately every 2 days and kept at room temperature.

\section{Procedure}

Prior to the experiment, the rats were trained to consume a $10 \%$ sucrose solution during dipper-magazine training. In these sessions, sucrose was delivered according to a variable time $60 \mathrm{~s}$ schedule of reinforcement, and head entries into the dipper chamber were recorded. When head entries occurred for more than $80 \%$ of the sucrose deliveries, the magazine training was finished and sucrose delivery was contingent on pressing a lever on a variable ratio (VR) schedule of reinforcement. The requirement for sucrose 
reinforcement was increased from VR2 to VR10 within approximately 12 sessions. During these and the subsequent phases, the position of the active lever (left or right) was counterbalanced and signaled by a white light above the lever. All of the sessions ended after $30 \mathrm{~min}$ or 200 sucrose deliveries.

Self-administration training. Alcohol self-administration training was based on a modified sucrose fading procedure. The solutions were delivered according to a VR10 schedule and presented as the following: $7.5 \%$ sucrose- $10 \%$ alcohol, $5 \%$ sucrose- $10 \%$ alcohol, $2.5 \%$ sucrose- $10 \%$ alcohol, and $0 \%$ sucrose- $10 \%$ alcohol. Transitions among solutions occurred when the rat drank active doses of alcohol $(>0.3 \mathrm{~g} / \mathrm{kg})$ for at least 3 days. Self-administration training finished when the rats consumed active doses of $10 \%$ alcohol for 8 consecutive days. After completing self-administration training, alcohol was delivered according to a variable interval (VI) $10 \mathrm{~s}$ schedule and then VI $15 \mathrm{~s}$ schedule. Once responding on the VI 15 s schedule stabilized, the baseline began.

Baseline. In baseline sessions, the rats could self-administer alcohol according to a two-component schedule of reinforcement that delivered two different alcohol doses $(5 \%$ and $15 \%)$. In one of the components, responses on the VI $15 \mathrm{~s}$ schedule resulted in the delivery of $5 \%$ alcohol. In the other component, responses on the VI $15 \mathrm{~s}$ schedule resulted in the delivery of $15 \%$ alcohol. Components alternated daily in order to facilitate discrimination between alcohol concentrations and were signaled by the active lever (left or right). The lever that was associated with each component was counterbalanced across subjects.

Extinction 1: Resistance to change. After the response rate stabilized on the multiple schedule, the first extinction phase began. Ten extinction sessions (five sessions 
with each dose) were performed. In the extinction sessions, the components were presented as in the baseline session, but the responses had no programmed consequences.

Extinction 2: Preference for stimulus associated with each dose. After the first extinction phase, the rats were returned to the baseline condition for approximately 30 days. A second extinction condition was then programmed to assess preference for the stimuli that were associated with each dose. Over 10 sessions, stimuli that were related to both doses were presented simultaneously, but the responses had no programmed consequences.

Concurrent schedule: Preference for a solution. After the second extinction condition, the rats were returned to the baseline condition for 30 days, after which preference for alcohol concentrations was measured using a concurrent schedule of reinforcement (VI 15 s-VI 15 s). A 0.5 s changeover delay was implemented for switching from one option to the other. This condition lasted for approximately 25 days. The last five sessions of extinction were used in the analysis.

\section{Data Analysis}

Paired-sample $t$-tests were used to compare consumption $(\mathrm{g} / \mathrm{kg})$, the reinforcement rate, and the response rate during baseline. Response and reinforcer rates were calculated as the number of lever presses and dipper presentations, respectively. Resistance to extinction was calculated as the log proportion of the response rate during extinction relative to the baseline response rate. To perform this calculation, the response rate for each extinction session was divided by the average response rate during baseline, obtained from the last 5 days before extinction and then transformed into logarithmic units (Nevin \& Grace, 2000). Preference was calculated as the relative response rate for a stimulus (second extinction session) or a dose (concurrent schedule). 
Repeated-measures analysis of variance (ANOVA), with component (5\% or $15 \%$ alcohol) and session of extinction as the within-subjects factors, was used to assess the resistance to extinction (during the first and second extinction sessions) and concurrent schedule.

Statistical significance for all of the tests was defined as $\alpha=0.05$. Significant violations of the sphericity assumption in the ANOVA were subjected to GreenhouseGeisser correction. The tests on which this correction was applied are evident in the fractional values of the $d f$ in the ANOVA.

\section{Results}

\section{Baseline}

Figure 1a shows the average dipper deliveries that were obtained in the last five sessions before extinction. The mean dipper deliveries were higher in the $5 \%$ component ( $\mathrm{M}=2.24)$ than in the $15 \%$ component $(\mathrm{M}=1.54)$, but this difference was not statistically significant $\left(t_{4}=2.06, p=.1\right)$. 

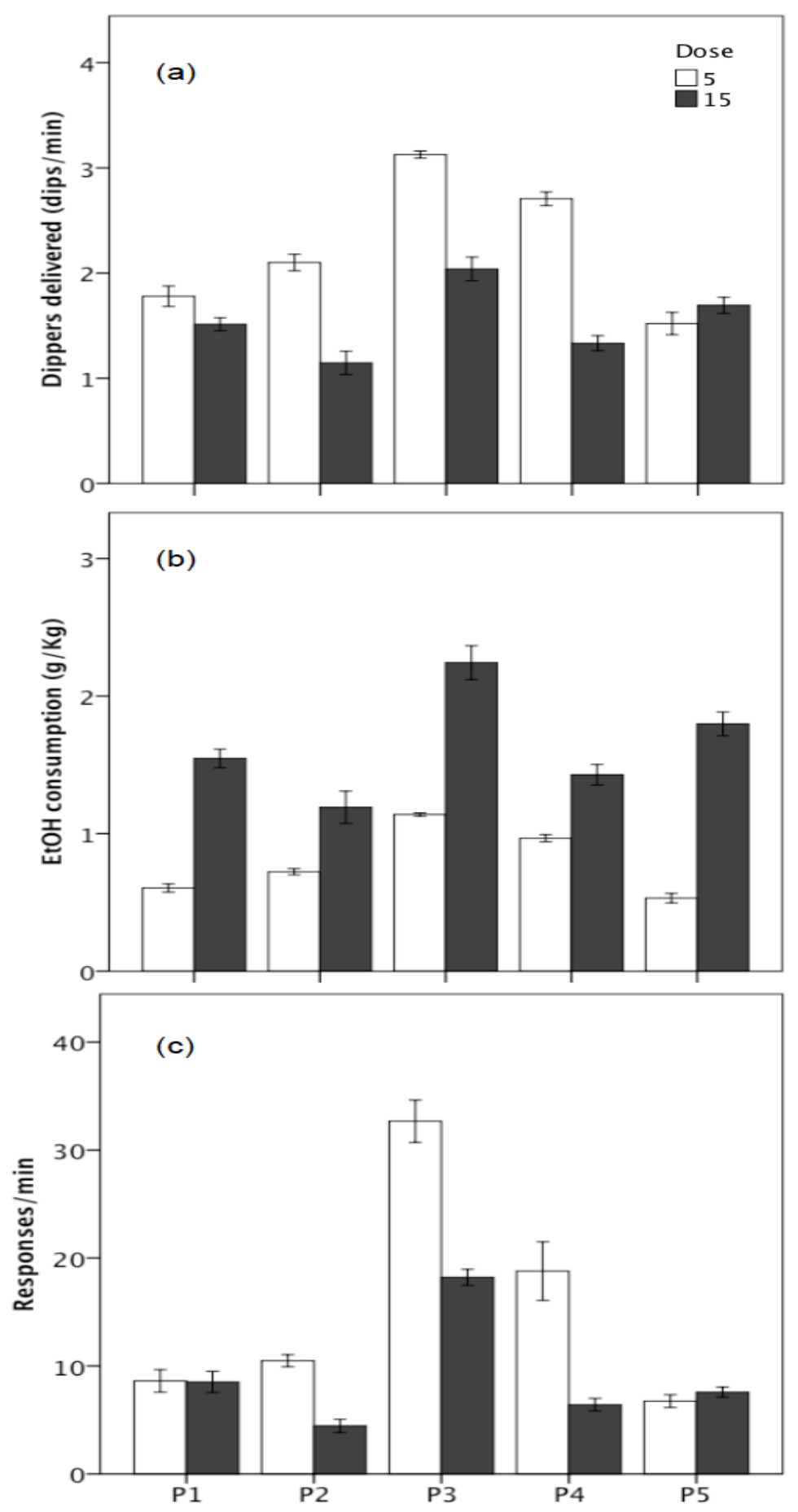

Figure 1. Baseline dipper deliveries per minute, alcohol delivered $(\mathrm{g} / \mathrm{kg})$, and responses per minute. The data correspond to the last five sessions of baseline. Black bars represent the $15 \%$ component, and white bars represent the $5 \%$ component 
Figure $1 \mathrm{~b}$ shows alcohol consumption $(\mathrm{g} / \mathrm{kg})$ during the five sessions before extinction. For all of the rats, more alcohol was delivered in the $15 \%$ component $(M=.79)$ than in the $5 \%$ component $(\mathrm{M}=1.67)$. This difference was statistically significant $\left(t_{4}=-\right.$ $5.14, p=.007)$. Figure $1 \mathrm{c}$ shows the mean response rate (responses per minute) in the five sessions before extinction. The average response rate was higher in the $5 \%$ component (M $=15.64)$ than in the $15 \%$ component $(M=9.04)$, but this difference was not statistically significant $\left(t_{4}=2.466, p=.07\right)$.

\section{Resistance to Extinction}

Figure 2 shows the resistance to change during the first and second extinction conditions. Overall, the resistance to extinction in the presence of stimuli that were related to alcohol concentrations, presented either separately or concurrently, was greater in the $15 \%$ component. This was confirmed by a significant main effect of component during the first $\left(F_{1,4}=46.88, p=0.002, \mathrm{n} 2=.92\right)$ and second $\left(F_{1,4}=16.06, p=.01, \mathrm{n} 2=.8\right)$ conditions of extinction.

The effect of session on the resistance to extinction was less clear. During the first extinction condition, responding decreased as sessions increased $\left(F_{4,1}=17.954, p=.006\right.$, $\mathrm{n} 2=.81)$. In the second extinction condition, the effect of session was not statistically significant. The dose $\times$ session interaction was not statistically significant. 

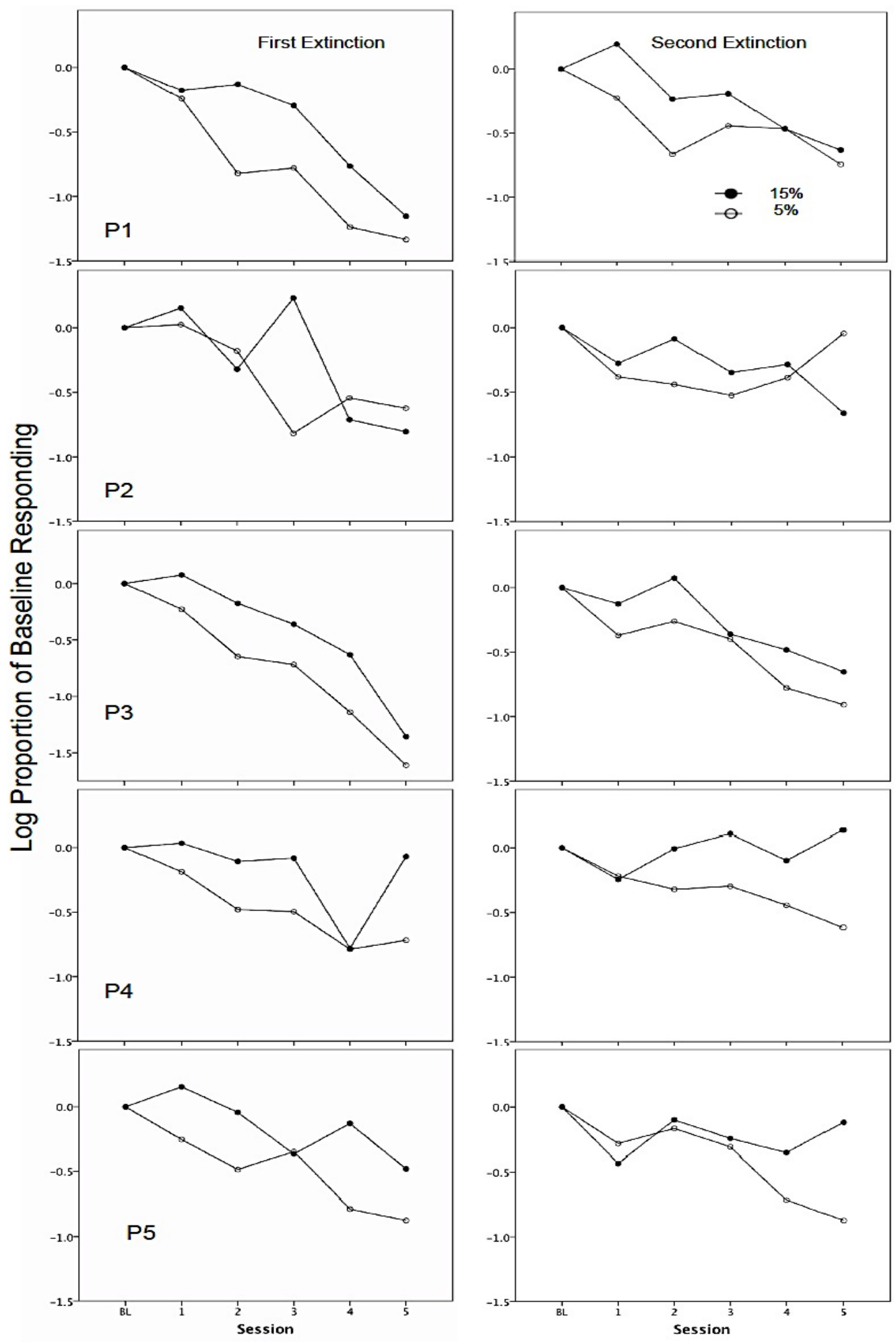

Figure 2. Resistance to change during extinction sessions. The log proportion of baseline responses per minute are presented. Black markers represent persistence in the $15 \%$ and white markers represents persistence in the $5 \%$ component 


\section{Preference}

Preference was assessed at two time points: first in the presence of stimuli that were related to each alcohol concentration with no solutions available (second extinction condition) and then in the concurrent schedule with the solutions available. The dose $x$ session $(2 \times 5)$ repeated-measures ANOVA revealed no effect of dose on response frequency during the second extinction condition or preference test. The effect of session and dose $\times$ session interaction were not statistically significant. Figures 3 and 4 show relative response rates for the $15 \%$ concentration during the second extinction condition and preference test, respectively. Values around 50\% indicate no difference between doses. No significant effect of dose on the relative response rate during the second extinction condition was found.

A Spearman correlation test showed a significant correlation between preference during both tests (with and without alcohol available; rs $(4)=.9, p=.03$ ). Additional correlation tests showed that preference for a context (extinction 2) or for a solution (preference test) was unrelated to any other variable, including responding during baseline, relative persistence, and total alcohol consumption during baseline. 


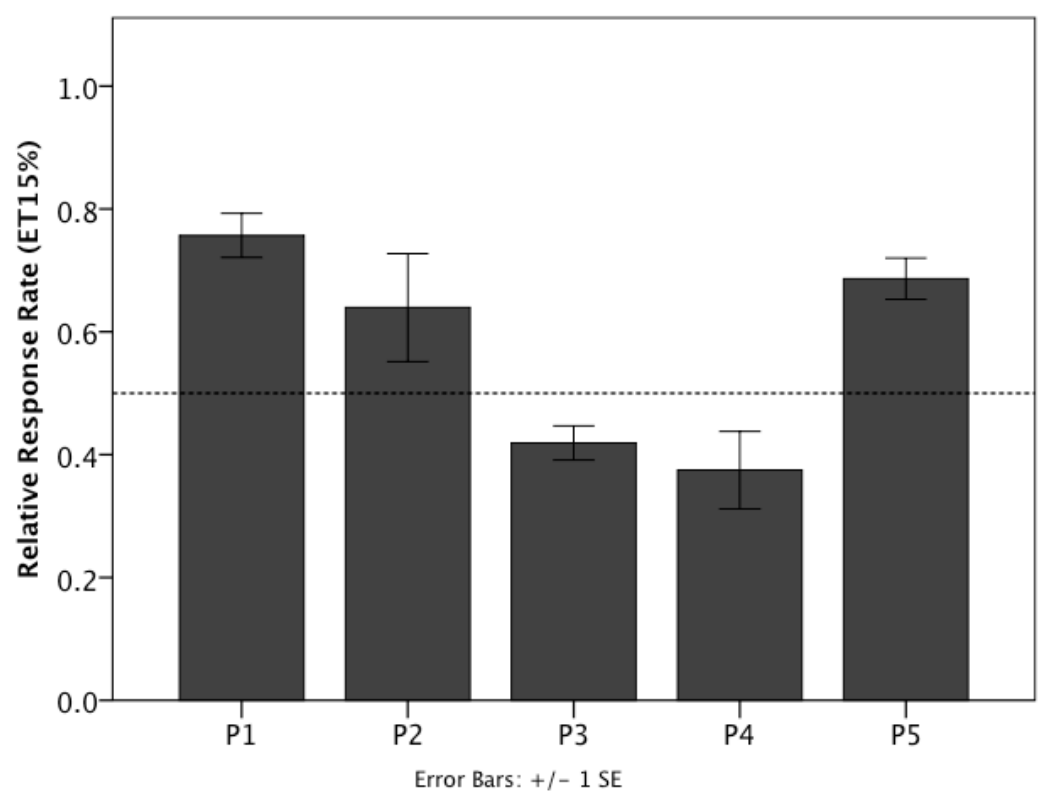

Figure 3. Relative response rate in the presence of the $15 \%$ alcohol-related stimulus during the second extinction session. The data are means of the 5 days of extinction for each concentration.

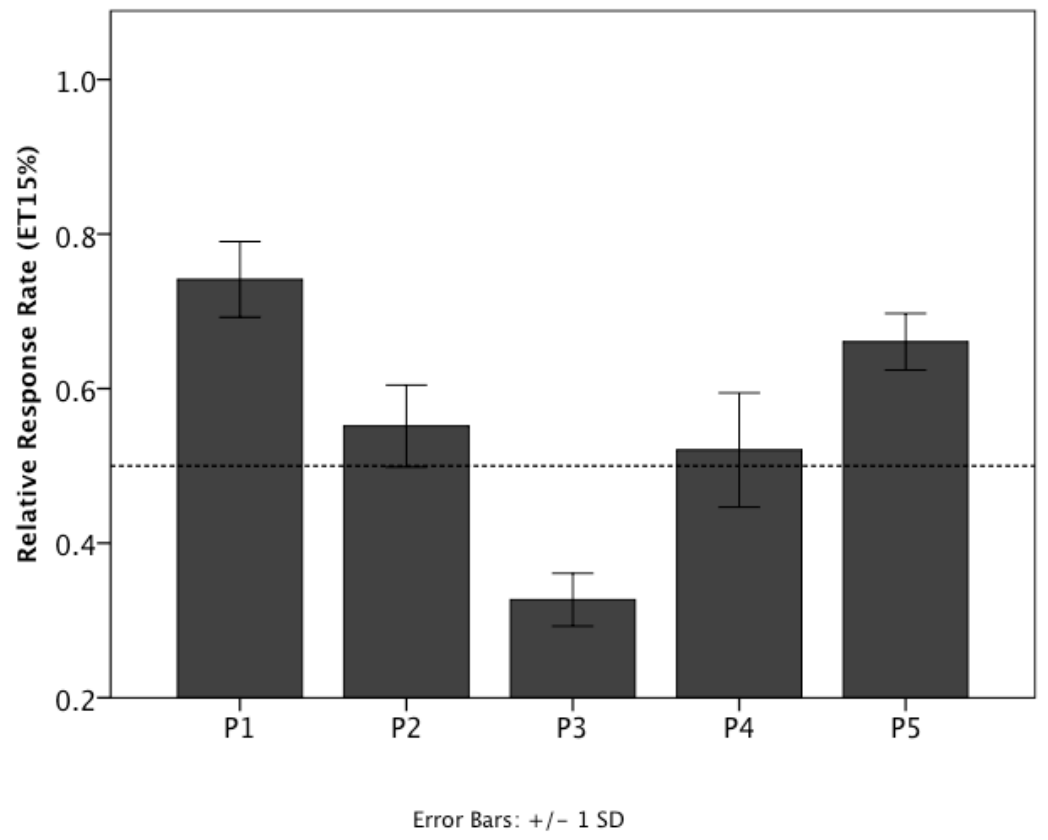

Figure 4. Relative response rate for the $15 \%$ alcohol concentration during the concurrent schedule. The data are means of the last 5 days of the concurrent schedule phase. 


\section{Discussion}

Alcohol-related contexts have been shown to induce persistence (Cortés-Patiño, Serrano, \& Garcia-Mijares, 2016; Jimenez-Gomez \& Shahan, 2007; Shahan \& Burke, 2004) and reinstatement (Bienkowski et al., 1999; Maccioni et al., 2007) of alcohol seeking. The purpose of the present study was to investigate whether a context that is related to different alcohol concentrations causes differential persistence in the absence of alcohol. We also assessed whether the alcohol concentration affects the preference for an alcohol-related context.

The analysis of baseline responding showed that most of the rats exhibited a higher response rate for the lower alcohol concentration $(5 \% \mathrm{v} / \mathrm{v})$. This finding is consistent with previous studies that showed that lower alcohol concentrations are related to higher response rates (Elmer et al., 1987; Meisch \& Thompson, 1974). However, the resistance to change during extinction followed an opposite pattern, in which the persistence of alcohol seeking was greater in the context that was related to the higher concentration. These findings are consistent with BMT, in which the response rate and persistence are two separate aspects of operant behavior, and persistence is determined by the Pavlovian stimulus-reinforcer relationship (Nevin \& Grace, 2000)

Using a different experimental design, Beardsley, Lemaire, and Meisch (1993) reported similar results with regard to alcohol concentration and persistence. They also used a multiple schedule of reinforcement, but they used alcohol and extinction as the two components of the schedule, and the duration of the extinction component was the disrupter. Their results showed that increasing the duration of the extinction component had a smaller effect on alcohol seeking when high alcohol concentrations were delivered in the 
alcohol-related context. This result is consistent with our findings and suggest that higher alcohol concentrations produce responding that is more resistant to disruption.

Notably, preference for an alcohol-related stimulus (i.e., in the second extinction sessions) or an alcohol solution (i.e., in the concurrent schedule) was unaffected by the alcohol concentration. This result is consistent with previous studies that showed that the effects of the magnitude of drug and non-drug reinforcers on preference are unclear. Martinetti, Khan, and Lewis (2007) investigated the effects of the alcohol concentration on preference for an alcohol solution using Matching Law. Their results showed that independent of the frequency of alcohol delivery, variations in the alcohol concentration did not affect preference, in which increases in the alcohol concentration were not consistently related to increases in response rates. This unclear effect of alcohol concentration on preference might be attributable to sensitivity to the orosensory features of different alcohol concentrations that show high individual variability, particularly in outbred rats (Bachmanov et al., 2003; Beardsley et al., 1993). Further experiments could explore whether measures of reactivity to the orosensory features of different alcohol concentrations are correlated with preference when assessed using models of choice, such as Matching Law.

In conclusion, the preference for alcohol and the persistence of alcohol seeking were not necessarily related. Previous studies reported divergence in these measures in pigeons that responded for food (Podlesnik, Jimenez-Gomez, \& Shahan, 2013). This difference between preference and resistance to change is central to understanding alcohol consumption and seeking because it highlights the role of Pavlovian relationships between the effects of contextual stimuli and drug reinforcement on the persistence of alcohol seeking. Preference and baseline responding were altered by alcohol consumption, 
including its orosensory features and satiation, whereas persistence depended entirely on the relationship between environmental contexts where alcohol intake occurred and the rate, amount, and quality of the reinforcers that were delivered in that context 


\section{Effects of Social Isolation on the Value of Alcohol-related Stimuli ${ }^{7}$}

Persistence of drug seeking has been explained by Behavioral Momentum Theory (BMT) as the product of the pavlovian learning about the relation between the context of self-administration and the features of drug-reinforcement. Accordingly, it has been shown that contexts related to more frequency of drug-reinforcement produces more persistence of drug-seeking (Jimenez-Gomez \& Shahan, 2007; Pyszczynski \& Shahan, 2011; T A Shahan \& Burke, 2004) and reinstatement of drug seeking after periods of non-consumption (P Bienkowski et al., 2000; Maccioni et al., 2007).

Recently it has been demonstrated that factors outside context of self-administration might also modulate persistence in the presence of alcohol-related context (Whitaker et al., 2013b). For instance, Cortés-Patiño, Serrano and Garcia-Mijares (2016) demonstrated that social isolation during rearing affect persistence in the presence of alcohol related stimuli. In the experiment, rats were reared either in isolation (ISO) or group interaction (INT). After rearing, rats were exposed to two contexts of alcohol self-administration. In the first context, alcohol delivery rate was three times higher than in the second context. Persistence was measured as resistance to extinction in the presence of the two alcohol-related contexts. ISO rats were significantly more persistent than INT rats in both contexts. This result suggests that social isolation effects on alcohol related behaviors go beyond consumption; it also affects persistence induced by alcohol-related stimuli.

Effects of isolation on persistence have been explained based on alterations in pavlovian learning: it seems that mechanisms involved in stimulus-stimulus learning are

\footnotetext{
${ }^{7}$ Diana Milena Cortés-Patiño, Catalina Serrano, Miriam García-Mijares
} 
sensitized in isolated reared rats, so learning about contextual stimuli linked to drugreinforcers would be enhanced in these animals (Harmer \& Phillips, 1998; Whitaker et al., 2013). If that were the case, manipulating parameters of the pavlovian relation "contextdrug" should have a differential effect on persistence by isolated reared rats compared to grouped reared rats.

In order to get more fully acquainted with the effects of isolation on context-induced persistence the present experiments manipulated parameters of reinforcement, others than frequency, that alter the pavlovian relation "context-drug" and see how early social isolation influences persistence in alcohol-related contexts. In the first experiment it was observed whether persistence of seeking in context related to different alcohol concentrations, i.e., magnitudes, was affected by social isolation. In the second experiment it was observed whether social isolation differentially affected persistence in contexts related to alcohol compared to context related to sucrose.

\section{Experiment 1}

Previous experiments have shown that isolated rats prefer solutions with high alcohol concentrations compared to rats reared in groups. Wolffgramm \& Heyne (1991) used a four-bottle paradigm to examine consumption of three alcohol concentrations $(5 \%, 10 \%$ and $20 \%$ ) and water in rats reared either in isolation, group cages (free social interaction) or contact cages (social interaction was allowed throughout a wire mess). Rats reared in isolation consumed relatively more alcohol from the $20 \%$ alcohol solution meanwhile group reared rats preferred 5\% alcohol solution. A similar result was reported by Hall, Huang, Fong, Pert, \& Linnoila (1998). In their experiment it was assessed consumption of 
$2 \%, 4 \%, 8 \%$ and $16 \%$ alcohol solutions by two strains of rats Fawn Hooded (alcohol preferring rats) and Wistar rats reared either in isolation or group conditions. They found that regardless of the strain, rats reared in isolation preferred higher alcohol concentrations.

Although the effects of isolation on consumption of different alcohol concentrations seem to be consistent, it is not known whether differences between isolated and group reared rats on consumption would also be observed on seeking for different alcohol concentrations, and more important if the seeking in absence of alcohol is increased in contexts related to higher alcohol doses.

\section{Method}

\section{Subjects}

Twenty male Wistar rats were obtained from the Institute of Biomedical Sciences (ICB) of University of São Paulo at the age of 21 days.

\section{Environmental Conditions and Apparatus}

Rats were randomly assigned to one of two experimental conditions: Social Isolation (ISO) or Social Interaction (INT). In order to ensure that all subjects experienced the rearing conditions during critic neurologic development, rats were assigned to the groups right after arrival to the laboratory and maintained in these conditions for 60 days before the experimental phase began. Rats in INT condition were housed four per cage in ALESCO polysulfona mini-isolators (48 x 34 x $25 \mathrm{~cm}$ ). Rats in ISO condition were housed individually in ALESCO polysulfona mini-isolators (37 x 24 x $24 \mathrm{~cm})$. Bedding was changed daily for the INT rats, and every three days for ISO rats. 


\section{Solutions}

The solutions were prepared with $99 \%$ ethanol, table sugar and tap water. Ethanol concentrations were calculated vol/vol (ethanol/tap water) and sucrose solutions were calculated wt/vol (sucrose/tap water). All solutions were mixed daily.

\section{Procedure}

After 60 days of rearing in the experimental conditions, rats were trained to selfadminister alcohol following a fading procedure, previously described by Cortés-Patiño et al. (2016). Prior to the beginning of the training, rats were food deprived and underwent lever-pressing training for a solution of $10 \%$ sucrose (SUC). Initially, SUC was delivered according to a CRF schedule then deliveries were made according to a VR schedule. VR values increased from VR2 to VR10 in approximately four days. This last schedule of reinforcement was used for self-administration training.

In the first part of the self-administration training, SUC concentration was kept at $10 \%$ while ET concentration gradually increased from $2.5 \%$ to $10 \%$. In the second part of the procedure, the ET concentration was kept constant at $10 \%$ and SUC concentration gradually decreased from $10 \%$ to $0.25 \%$. Self-administration training finished when rats consumed active doses of ET10\%-SUC0.25\% for at least eight days. The entire selfadministration training lasted approximately two months. All sessions in this phase ended after 30 minutes. Following self-administration training, alcohol was delivered according to VI 15s schedule. VI values were selected without replacement from a 10 intervals list constructed according to the Fleshler and Hoffman (1962) progression. When responding on VI 15s schedule was steady, baseline began. 
Baseline. In baseline, alcohol was delivered according to a two-component multiple schedule delivering different alcohol concentrations (5\% and 15\%). In one of the components, responses according to a VI 15 s resulted in the delivery of a solution of $5 \%$ alcohol. In the other component, responses according to a VI 15s resulted in the delivery of $15 \%$. In order to facilitate discrimination between doses, each component was presented daily. The active lever (left or right) signaled which component was in effect. When left lever was active, the white light above the lever was turned on and vice versa. Lever associated to each component was counterbalanced among subjects. Sessions in this phase ended after 30 minutes.

Extinction. When response rate on the multiple schedule was steady (i.e. five consecutive sessions without trend as determined by visual inspection, approximately 90 session) six extinction sessions were presented (three with each component). On extinction sessions, components were presented as in baseline, light was turned on and the solution was placed outside the chamber, but the dipper did not lift.

Preference. After extinction sessions, baseline sessions were re-introduced for 20 days after which preference for a solution was measured. During the preference sessions, both solutions ( $5 \%$ and $15 \%$ ) were delivered according to a concurrent schedule of reinforcement VI 15s-VI 15s. A 0.5 change over delay was imposed for switching from one option to the other. This condition lasted for 5 days.

\section{Data Analysis}

Measures of consumption ( $\mathrm{g} / \mathrm{kg}$ per session), reinforcement rate and response rate for each component were obtained during baseline. Response and reinforcer rates were 
measured as the number of lever presses and dipper presentations, respectively, per minute of time spent in each component during the entire session. Mixed ANOVA was performed to analyze the data of this phase, using component as within-subject factor and rearing as a between-subject factor.

Resistance to extinction was calculated as the log proportion of response rate during extinction relative to baseline response rate. Statistical analyses of resistance to extinction were conducted by similar mixed ANOVA performed during baseline, but with session of extinction added as a second within subject variable. Preference was measured as the relative response rate for the higher alcohol dose (15\%). Relative response rate was calculated dividing the frequency of response for the $15 \%$ dose in a session by the total frequency of response during the session (responses in the $5 \%+$ responses in the $15 \%$ component). Statistical analysis of response frequency for each concentration were conducted by a mixed ANOVA with concentration as a within subject variable and rearing as between subject factor. Differences between groups in relative response rate were analyzed by $t$ tests.

For all analysis, effect sizes were computed using $\eta^{2}$, and statistical significance was determined using as criterion $\mathrm{p}<.05$.

\section{Results}

\section{Baseline}

Figure 1 displays differences in measures between the groups during the last five days of baseline. Panel $a$ in Figure 1 shows mean of dipper deliveries of the last five sessions before extinction. For ISO and INT rats, dipper deliveries were higher in the $15 \%$ component $[F(1,21)=91.16, p<.0001, \mathrm{n} 2=0.81]$; nevertheless, ISO rats obtained more 
alcohol deliveries from $15 \%$ and $5 \%$ components $[F(1,21)=7.473, p=.01, \mathrm{n} 2=0.26]$. The interaction term Component X Group was not statistically significant.

Panel $\mathrm{b}$ in Figure 1 shows mean amount of alcohol consumption expressed in $\mathrm{g} / \mathrm{Kg}$. Both groups consumed more alcohol from the $15 \%$ component $[F(1,21)=31.865, p<$ $0.001, \mathrm{n} 2=0.6]$. However, ISO rats consumed higher doses of alcohol from $5 \%$ and $15 \%$ components $[F(1,21)=11.25, p<0.003, \mathrm{n} 2=0.35]$. The interaction term was not statistically significant.

Panel $\mathrm{c}$ in Figure 1 displays mean response rate in both components. Higher response rates were observed in the $5 \%$ component for both groups $[F(1,21)=40.37, p<0.001$, $\mathrm{n} 2=0.65]$, and ISO rats exhibited higher response rates in both of the components $[F(1,21)$ $=15.98, p=0.001, \mathrm{n} 2=0.43]$. The interaction term was not statistically significant. 

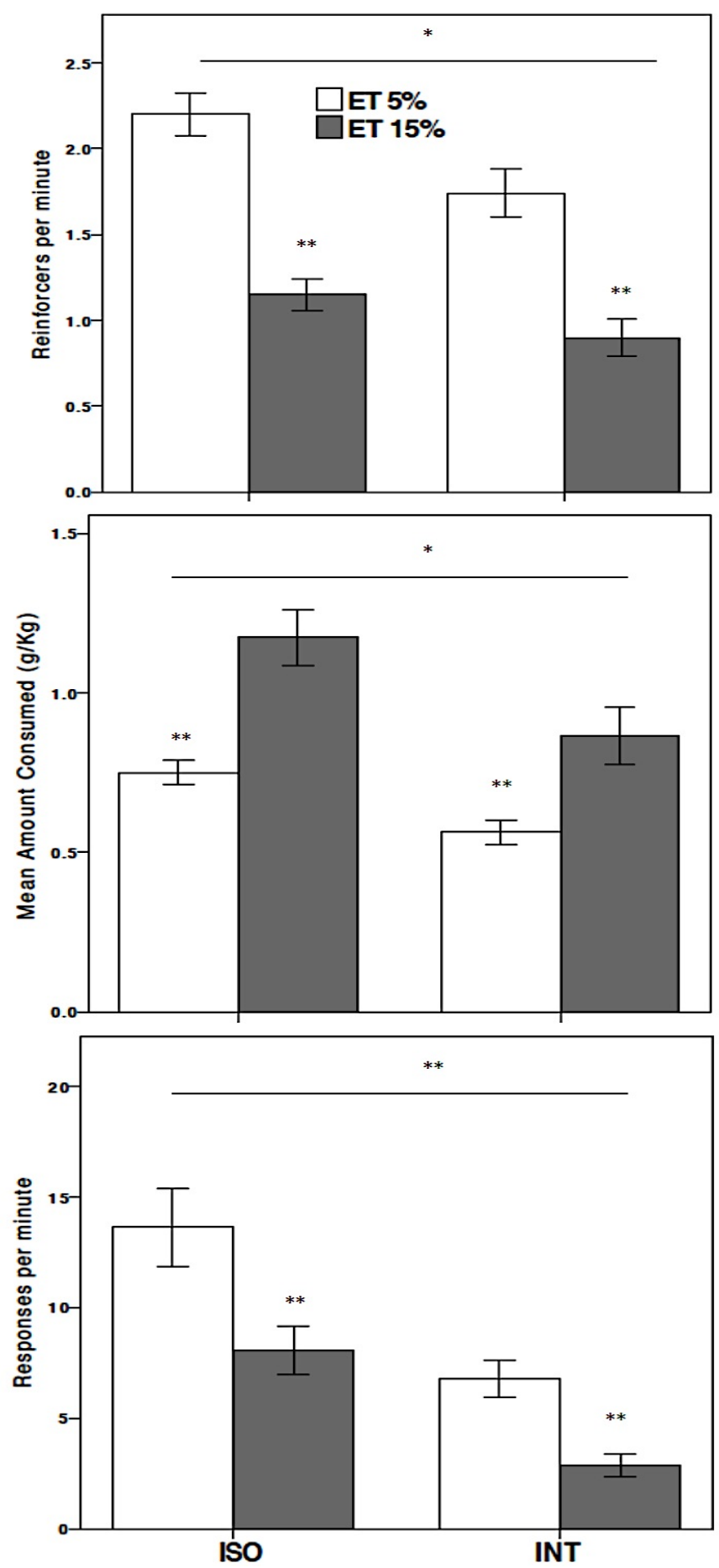

Figure 1. Baseline Dippers/min, Et g/kg delivered and Responses/min. Data correspond to the last five sessions of baseline. Grey bars represent the rich component, and white bars represent the lean component. Asterisks represent significant differences (*, $\mathrm{p}<0.05 ; * *, \mathrm{p}<0.001)$ 
Resistance to extinction. Figure 2 displays log proportion of baseline responding during the three extinction days for ISO and INT rats. A higher log proportion of baseline responding during the extinction sessions evidences greater resistance to extinction. For both groups, resistance to extinction decreased as session increased $[\mathrm{F}(1.12,22.51)=28.63$, $p<0.001, \mathrm{n} 2=0.58]$. Additionally, responding during extinction was higher in the $15 \%[\mathrm{~F}$ $(1,20)=6.45, p=0.04, \mathrm{n} 2=0.24]$. No main effect of group was found $(\mathrm{p}>0.05)$, nevertheless, the interaction effects between Group X Session and Group X Component X Session were significant $[\mathrm{F}(1.47,29.53)=4.01, p=0.02, \mathrm{n} 2=0.16 ; \mathrm{F}(1.8,36.11)=3.78$, $\mathrm{p}=0.03, \mathrm{n} 2=0.15$, respectively]. Planned comparisons among different sessions showed that ISO rats exhibited a higher response rate in the $15 \%$ component than INT rats during the first extinction session $(\mathrm{p}=0.04)$, however this difference was not maintained the remaining extinction sessions. No differences in responding between the groups were found for the $5 \%$ component. 

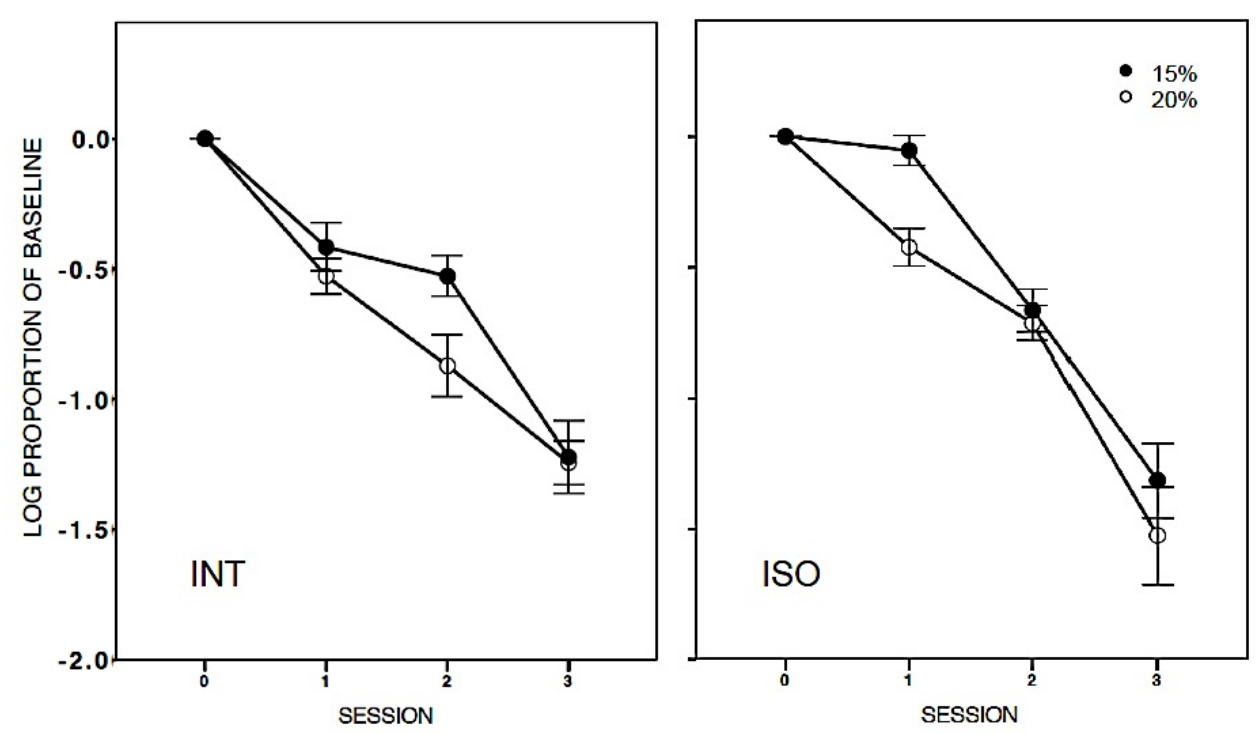

Figure 2. Resistance to change during extinction sessions. Log proportion of baseline responses per minute are presented for INT and ISO groups. Black markers represent responding in the $15 \%$ component, and white markers represent responding in the $5 \%$ component.

\section{Concurrent Schedule}

Figure 3a shows response frequency for each alcohol concentration during the concurrent schedule. Overall, rats responded more for the 5\% solution than for the $15 \%$ solution $[\mathrm{F}(1,20)=21.88, p<.001, \mathrm{n} 2=.5]$. Additionally, ISO rats exhibited higher response frequency than INT rats $[\mathrm{F}(1,20)=9.5, p=.006, \mathrm{n} 2=.32]$. The interaction term was not statistically significant. Analysis of relative response rate for a solution showed that rats in both groups preferred 5\% alcohol concentration (Figure 3b). No differences between ISO and INT rats were found in preference of an alcohol concentration $(p>0.05)$. 

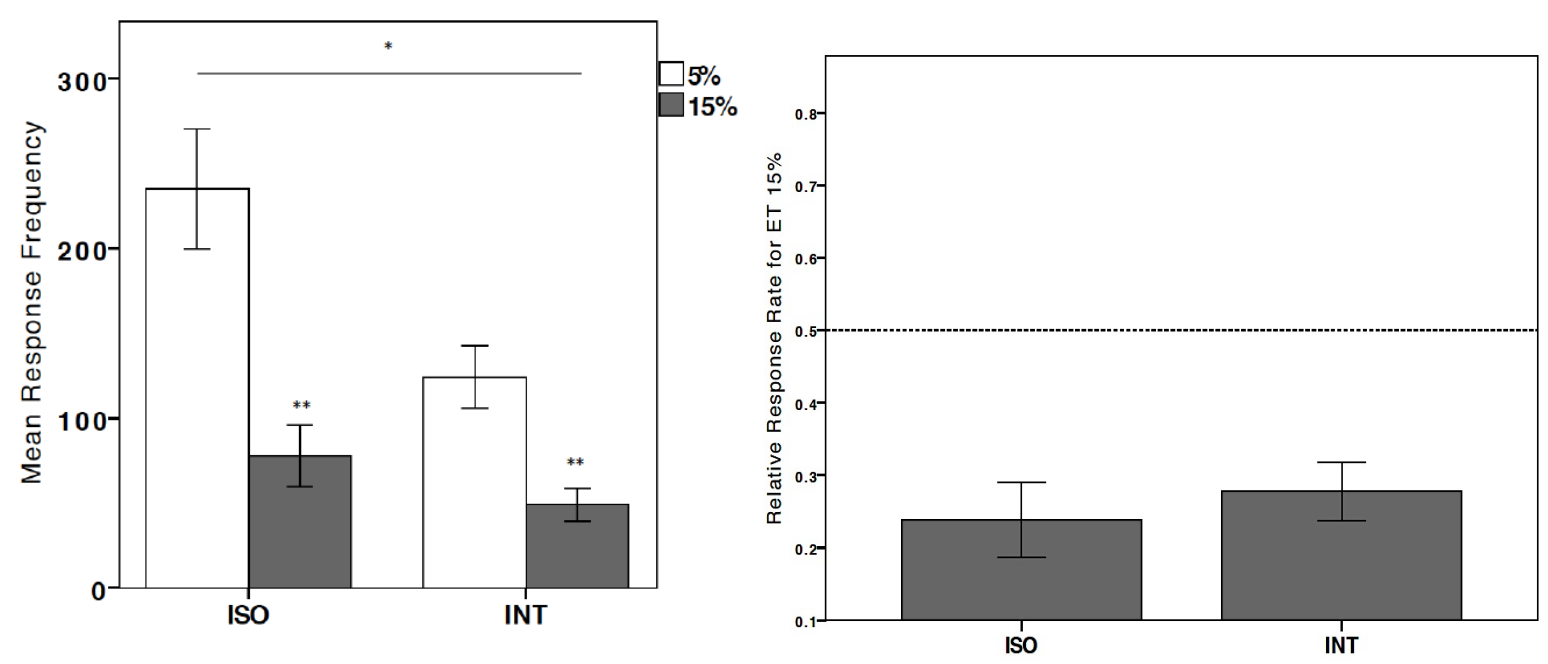

Figure 3. (a) Response frequency for 5\% and $15 \%$ alcohol solutions during the concurrent schedule. Grey bars represent the rich component, and white bars represent the lean component. (b) Relative response rate for the 15\% alcohol solution during the concurrent schedule for ISO and INT rats. Measure above the line represent preference for the $15 \%$ solution and measure under the line represents preference for the $5 \%$. Asterisks represent significant differences $(*, p<0.05 ; * *, p<0.001)$.

\section{Discussion}

To our knowledge, this is the first study to assess the effects of social rearing on operant consumption of different alcohol concentrations. Although the results showed that ISO rats consumed significantly more alcohol than INT rats, it was found that regardless of the rearing conditions, rats consume more and prefer the lower alcohol concentration (5\%). Some studies with free consumption paradigms have reported that rats reared in isolation consume preferentially higher doses (Hall et al., 1998a; Schenk, Gorman, \& Amit; J Wolffgramm \& Heyne, 1991). The discrepancy between the present experiment and previous reports might be due to the features of the self-administration. Other studies used 
free consumption in the homecage with solutions of alcohol and water available. As asserted by Samson (1998), consumption of a solution in free paradigms reflects primarily processes related to the ingestion of the solution (like satiation) or the pharmacological effect of the solution, meanwhile, operant paradigms of consumption are more sensitive to motivational properties of the solution.

Besides alcohol consumption, social isolation affected persistence in the context related to alcohol delivery, however, this effect was restricted to the first day of extinction and the $15 \%$ alcohol concentration. The transient effect might be related to features of the extinction procedure: during the extinction sessions component related to each dose was presented for an entire 30 minutes session without any consequences. It is possible that extinction rate was faster than the observed in regular multiple schedules in which components alternate within the session, so the effects of social rearing might be shadowed in the posterior extinction sessions

Notably, the divergence between preference and persistence was found in both rearing groups: ISO and INT rats responded more and preferred the 5\% solution, also both groups exhibited more resistance to extinction in the $15 \%$ component. This divergence is according to the observed in previous studies with pigeons (Podlesnik et al., 2013) and rats (see Chapter Two) and confirm that preference and resistance to change are independent behavioral phenomena: meanwhile preference is related to baseline responding, resistance to change depends upon the sources of reinforcement in the context.

\section{Experiment 2}

The second experiment intended to assess whether isolation differentially affects persistence in alcohol related contexts compared to sucrose-related contexts. Previous experiments had shown that alcohol consumption, but not sucrose consumption, is affected 
by rearing conditions (Cortés-Patiño et al., 2016; Deehan, Palmatier, Cain, \& Kiefer, 2011b; Hall et al., 1998a). Although these findings suggest that effects of rearing on consumption might be specific to alcohol, experiments that evaluate learning about stimuli related to reinforcers indicate that effects of rearing could be extended to other reinforcers.

Harmer and Phillips (1998) trained isolated and grouped reared rats in a discriminative task in which an arbitrary stimulus was related to sucrose delivery. The approach behavior in presence of the stimulus $(\mathrm{CS}+)$ and the avoidance behavior during the inter-trial interval (CS-) were measured as an indicative of the learning about the pavlovian relation between the stimulus and the sucrose. Isolation rearing enhanced the acquisition of the approach behavior, suggesting that learning about pavlovian relations is enhanced in isolated subjects. This finding was supported by further experiments using non-operant procedures. (Harmer \& Phillips, 1998; Phillips, Harmer, \& Hitchcott, 2002).

If, as asserted by BMT, persistence depends upon pavlovian learning and could be considered as an index or the value of a conditioned stimuli, we could argue that stimuli related to any source of reinforcement could acquire more value for isolated reared rats compared to group reared rats. Taking this into account, the present experiment evaluated whether isolation rearing affects specifically persistence for stimuli related to alcohol or it also affect the value of stimuli conditioned to other reinforcers like sucrose. 


\section{Methods}

\section{Subjects}

Twenty male Wistar rats were obtained from the Institute of Biomedical Sciences (ICB) of University of São Paulo at the age of 21 days. The environmental conditions and apparatus were the same as in the Experiment 1.

\section{Procedure}

The experimental phases were the same as in Experiment 1. During baseline the same multiple schedule was used, but the components were associated to the delivery of a solution of $10 \%$ alcohol (Alcohol Component) or an isocaloric solution of $14.3 \%$ sucrose (Sucrose Component). Extinction and preference phases were conducted in the same way than in Experiment 1.

\section{Results}

\section{Baseline}

Figure 4 shows differences in measures of response rate (4a) and reinforcer rate (4b) between the groups during the last five days of baseline. Overall, rats from both groups exhibited higher response and reinforcer rates in the SUC component $[\mathrm{F}(1,18)=522.67$, 693.21, $\mathrm{p}<0.001, \mathrm{n} 2>0.9$, respectively]; however, a significant main effect of group revealed that ISO rats responded more $[\mathrm{F}(1,18)=20.77, \mathrm{p}<0.001, \mathrm{n} 2=0.53]$ and gain more reinforcers $[\mathrm{F}(1,18)=24.41, \mathrm{p}<0.001, \mathrm{n} 2=0.57]$ than INT rats in both components. The interaction term Component X Group was also significant, showing that difference between ISO and INT rats were higher in the ET component $[\mathrm{F}(1,18)=7.58, \mathrm{p}=0.01, \mathrm{n} 2$ $=0.29$ ). Figure 5 shows mean amount consumed of ET in both components As expected, ISO rats consumed more ET than INT rats $[\mathrm{F}(1,18)=20.32, \mathrm{p}<0.001, \mathrm{n} 2=0.53]$. 


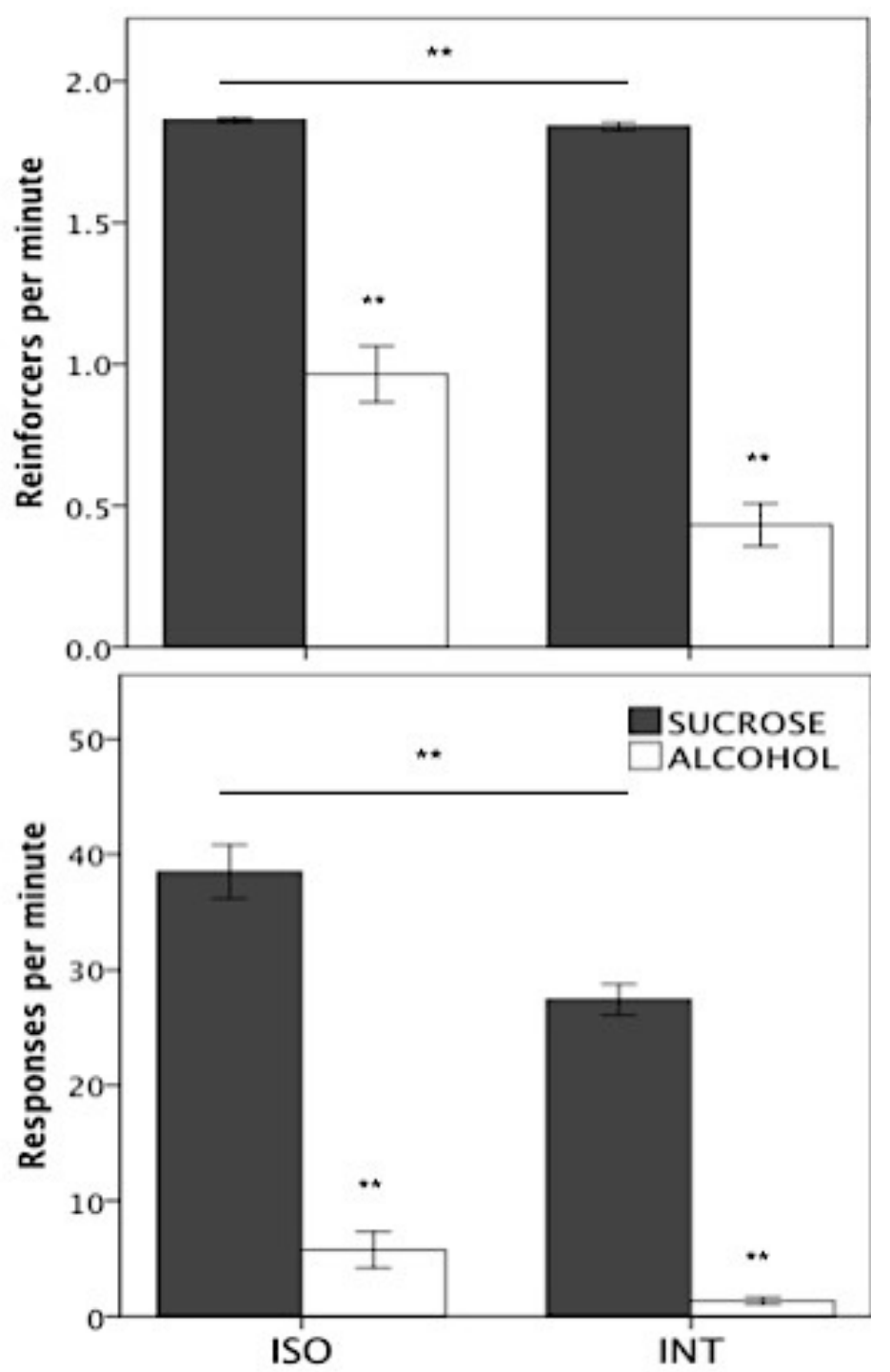

Figure 4. Baseline Reinforcers/min and Responses/min for Sucrose and Alcohol.

Data correspond to the last five sessions of baseline. Grey bars represent the sucrose component, and white bars represent the alcohol component. Asterisks represent significant differences $(*, \mathrm{p}<0.05 ; * *, \mathrm{p}<0.001)$ 


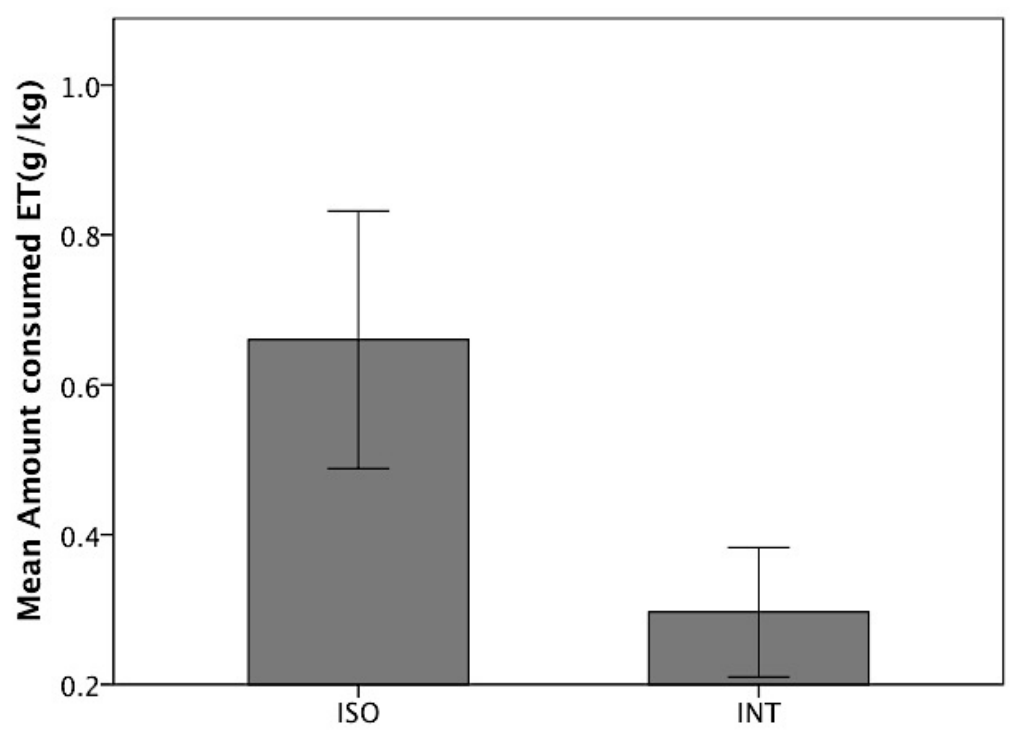

Figura 5. Mean amount of alcohol consumption per day $(\mathrm{g} / \mathrm{Kg})$.

\section{Extinction}

Figure 6 displays log proportion of baseline responding during the three extinction days for ISO and INT rats. Resistance to extinction decreased as session of extinction increased $[\mathrm{F}(2,32.88)=2.72, \mathrm{p}<.001, \mathrm{n} 2=0.85)$. ISO rats exhibited greater resistance to extinction in both components $[\mathrm{F}(1,18)=51.28, \mathrm{p}<.001, \mathrm{n} 2=.74)$. The interaction term Component X Group was significant, suggesting that ISO rats were more resistant in the alcohol component $[\mathrm{F}(1,18)=4.2, \mathrm{p}=.05, \mathrm{n} 2=0.22]$.

A fine-grained analysis of relative resistance to change showed that difference in the resistance to extinction between SUC and ET components was bigger in the ISO group (Fig 7), this is, ISO rats were relatively more persistent in the ET component than in the SUC component, meanwhile the relative persistence between components was nearly zero for the INT rats $[\mathrm{F}(1,18)=26.08, \mathrm{p}<.001, \mathrm{n} 2=.52)$. 

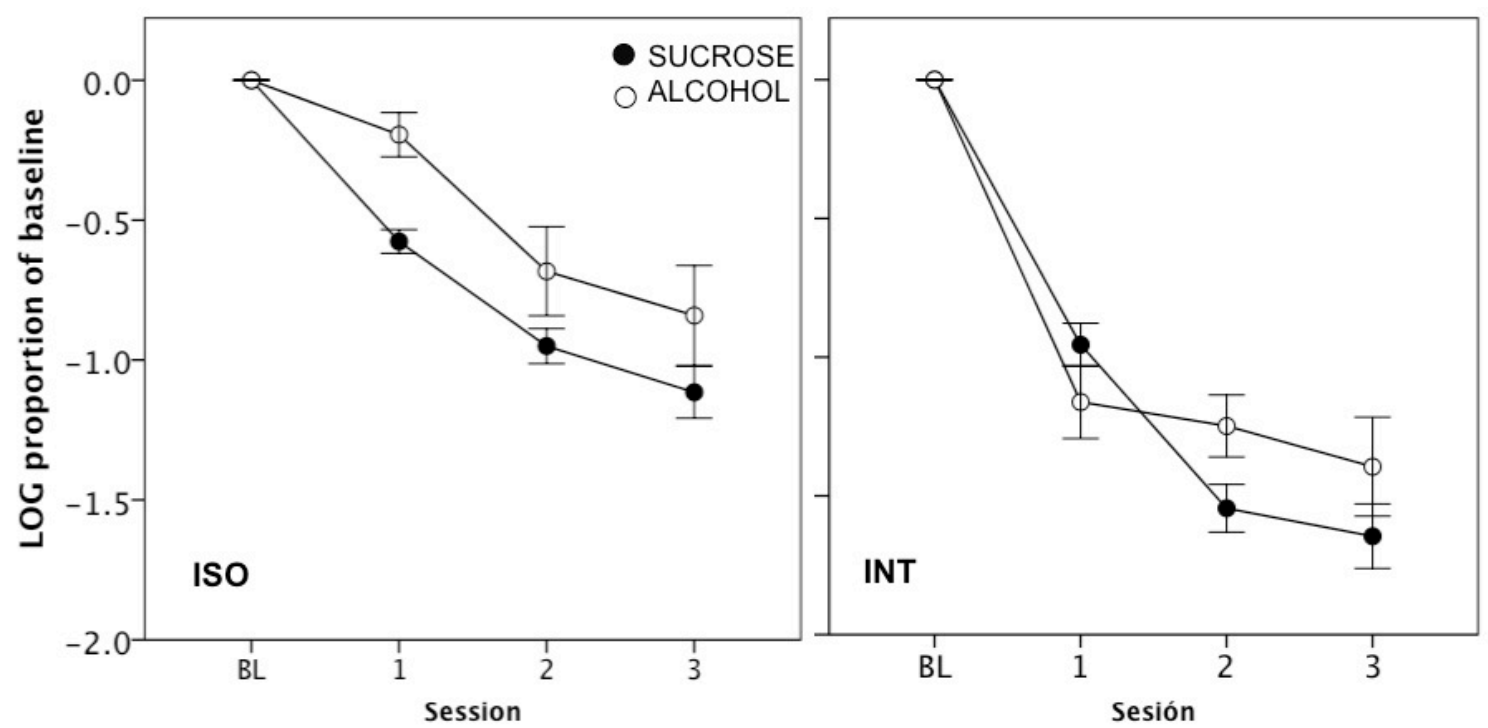

Figure 6. Resistance to change for sucrose and alcohol during extinction sessions.

Log proportion of baseline responses per minute are presented for ISO and INT groups.

Black markers represent responding in the SUCROSE component, and white markers represent responding in the ALCOHOL component. 


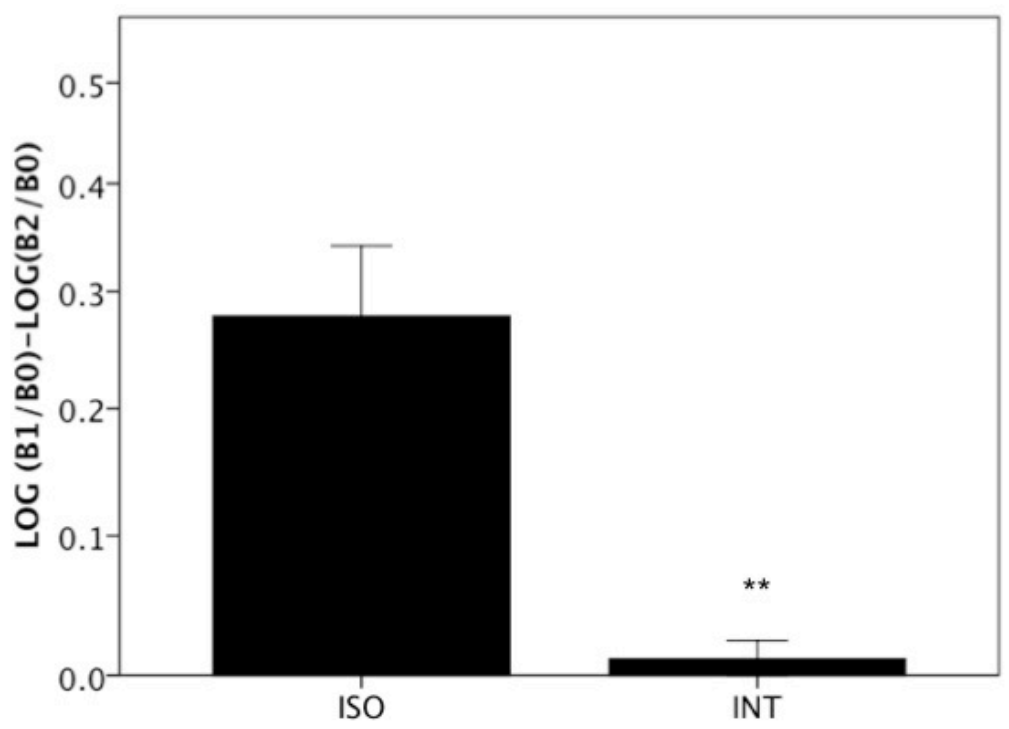

Figure 7. Relative persistence for Alcohol and Sucrose components during extinction. Analysis was made by subtracting the proportion of the baseline responding in the Sucrose component (B2/B0) from the proportion of baseline responding in the Alcohol component (B1/B0). Values near to zero indicate that persistence was similar in the two components. Data were collapsed across the three extinction sessions.

\section{Concurrent Schedule}

Analysis of response frequency in the concurrent schedule showed that ISO and INT rats responded more in the SUC component $[\mathrm{F}(1,18)=355,53, \mathrm{p}<0.001, \mathrm{n} 2=0.95)$. A significant main effect of group $[\mathrm{F}(1,18)=25.5, \mathrm{p}<0.001, \mathrm{n} 2=.58)$ and the interaction between Group X Component $[\mathrm{F}(1,18)=26.08, \mathrm{p}<0.001, \mathrm{n} 2=.59)$ revealed that ISO rats responded more during the concurrent schedule. Planned comparisons showed that ISO rats responded significantly more for $\mathrm{SUC}[\mathrm{t}(18)=5.28, \mathrm{p}<0.001)$ but there were no differences between the groups in response frequency for ET $(\mathrm{p}>0.05)$. No differences were found in the relative response rate 


\section{Discussion}

The study yielded two main conclusions: (1) social isolation increases persistence for alcohol and sucrose, however, this effect is major for alcohol (2) Social isolation does not affect preference for alcohol when sucrose is concurrently available, since both groups ISO and INT preferred sucrose to alcohol.

The results are according to the previous experiment showing that persistence in context related to alcohol is increased in isolated reared rats. Additionally, it was also found that isolation affected persistence for sucrose. To our knowledge, is the first time that operant persistence for sucrose is assessed under different social conditions, however, the result is according to previous research using pavlovian paradigms that showed that seeking for sucrose in context related to its delivery is increased by isolation. Taken together, the results evidenced that learning about stimuli related to reinforcers is enhanced by isolation, suggesting that isolation affects the value of conditioned stimuli.

The results of relative persistence showed that although isolation affect persistence for both, alcohol and sucrose, isolation had an increased effect for alcohol-related stimuli: meanwhile INT rats did not differ in persistence between alcohol and sucrose, ISO rats exhibited greater persistence in the Alcohol component compared to the Sucrose component. This finding suggests that isolation alters primarily the value of stimuli related to alcohol. Studies with cocaine and amphetamines using CPP had reported increased learning and resistance to extinction in isolated rats, thus we could argue that learning about drug-related stimuli seems to be enhanced in rats. Studies on neural mechanisms had shown that social isolation alters neural circuits involved in drug reinforcement; particularly, it has been shown enhanced plasticity glutamatergic neurons in the ventral 
tegmental area (VTA) an area involved in reward learning and drug addiction. Whitaker et al suggested that enhanced plasticity in this area could be the mechanism by which isolated rats are more sensible to stimuli related to drugs.

As a second conclusion, this study revealed that preference for a reinforcer is not necessarily related to the persistence for it. In a similar experiment Mace evaluated the effects of qualitatively different reinforcers on persistence. In their procedure, prior to baseline, rats had access to a two-bottle test preference in which they consumed solutions of sucrose or citric acid. Baseline and extinction test were performed with a regular multiple schedule. They found that rats were more persistent in the context related to the preferred reinforcer (sucrose) and conclude that behavior that is reinforced with a preferred reinforcer is more persistent that behavior reinforced with a less preferred reinforcer. Following Mace' results it was proposed that the construction of hedonic scales with different reinforcers could predict persistence in context related to different reinforcers.

Our results diverge from the ones from Mace' study. The preference test with the concurrent schedule showed that rats from both groups preferred sucrose to alcohol; relative response rate for sucrose was over $90 \%$ for most of the subjects, however the resistance to extinction test show that behavior of ISO rats were more persistent in the Alcohol component and for INT rats there were no differences between Sucrose and Alcohol Component. The divergence between preference and resistance to extinction found in our study confirm that although both are related. This finding is relevant since several studies had compared preference for drug sources like cocaine or alcohol to the preference for sucrose, and it has been shown that when sucrose is available most rats preferred sucrose. Based on those results it has been proposed that addiction to drugs depends on availability of other reinforcers in the environment. The present results showed that 
regardless of the preference for drugs, persistence engendered by drugs compared to other sources of reinforcement. 


\section{CONCLUSÕES}

1. Os resultados do presente trabalho dão sustento a hipótese de que o isolamento incrementa a persistência na procura de álcool. O incremento na persistência da procura foi observado em contextos associados a diferentes características de entrega de álcool. De acordo com o modelo da BMT, o incremento na persistência ocasionado pelo isolamento implica um aumento no valor de estímulos associados ao álcool em ratos isolados em comparação com ratos criados em grupo.

2. Os achados do presente trabalho concordam com reportes prévios que demonstram que o isolamento incrementa o consumo de álcool em situações livre e operantes.

3. Levando em consideração que a criação em condições de isolamento aumenta tanto o consumo como a persistência na procura de álcool, o presente trabalho se junta a outros reportes que sugerem que condições de estresse social em etapas iniciais do desenvolvimento são um fator de risco para os transtornos de abuso de álcool.

4. A separação observada entre a preferencia por álcool e a persistência em contextos associados ao seu uso sugere que tal como apresentado pela BMT a persistência é independente do consumo e depende de aprendizagens pavlovianas ente o contexto e as características do reforçador obtido.

5. O modelo de momento comportamental (BMT) permite a inclusão de variáveis organísmicas e ambientais que afetam a sensibilidade ao álcool como reforçador Futuras pesquisas poderiam fazer manipulações que permitam estabelecer mais claramente quais parametros da resistência à mudança são afetados pelo isolamento. 


\section{REFERENCIAS}

Araujo, N. P., Camarini, R., Souza-Formigoni, M. L. O., Carvalho, R. C., Abílio, V. C., Silva, R. H., ... Frussa-Filho, R. (2005). The importance of housing conditions on behavioral sensitization and tolerance to ethanol. Pharmacology Biochemistry and Behavior, 82(1), 40-45. http://doi.org/10.1016/j.pbb.2005.07.009

Battistich V, Hom A (1997). The Relationship between students'sense of their school as a community and their involvement in problem behaviors. American Journal of Public Health 87: 1997-2001

Bienkowski, P., Koros, E., Kostowski, W., \& Bogucka-Bonikowska, A. (2000). Reinstatement of ethanol seeking in rats: behavioral analysis. Pharmacology Biochemistry and Behavior, 66(1), 123-128.

Bienkowski, P., Kostowski, W., \& Koros, E. (1999). The role of drug-paired stimuli in extinction and reinstatement of ethanol-seeking behaviour in the rat. European Journal of Pharmacology, 374(3), 315-319. doi: http://dx.doi.org/10.1016/S00142999(99)00244-7

Brown V and Riley M (2005). Social support, drug use, and employment among lowincome women. The Am J Drug Alcohol Abuse 31: 203-223.

Chappell, A. M., Carter, E., McCool, B. A., \& Weiner, J. L. (2013). Adolescent rearing conditions influence the relationship between initial anxiety-like behavior and ethanol drinking in male Long Evans rats. Alcohol: Clinical and Experimental Research, 37 Suppl 1, E394-403. doi: 10.1111/j.1530-0277.2012.01926.x 
Deatherage, G., (1972). Effect of housing density on alcohol intake in the rat. Physiology and Behavior, 9, 55-57.

Deehan, G. A., Cain, M. E., \& Kiefer, S. W. (2007). Differential rearing conditions alter operant responding for ethanol in outbred rats. Alcoholism: Clinical and Experimental Research, 31(10), 1692-1698. http://doi.org/10.1111/j.1530-0277.2007.00466.x

Deehan, G. A., Jr., Palmatier, M. I., Cain, M. E., \& Kiefer, S. W. (2011). Differential rearing conditions and alcohol-preferring rats: consumption of and operant responding for ethanol. Behavioral Neuroscience, 125(2), 184-193. doi: $10.1037 / \mathrm{a} 0022627$

Ellison, G. (1987). Stress and alcohol intake: The socio-pharmacological approach. Physiology \& Behavior, 40 , 387-392.

Everitt, B. J., Belin, D., Economidou, D., Pelloux, Y., Dalley, J. W., \& Robbins, T. W. (2008). Review. Neural mechanisms underlying the vulnerability to develop compulsive drug-seeking habits and addiction. Philosophical Transactions of the Royal Society of London. Series B, Biological Sciences, 363(1507), 3125-3135. http://doi.org/10.1098/rstb.2008.0089

Files, F. J., Samson, H. H., Denning, C. E., and Marvin, S. (1998). Comparison of alcoholpreferring and nonpreferring selectively bred rat lines. II. Operant self-administration in a continuousaccess situation. Alcohol. Clin. Exp. Res. 22:2147-2158.

Fleshler M, Hoffman H (1962). A progression for generating variable-interval schedules. Journal of Experimental Analysis of Behavior 5:529-530. 
Füllgrabe MW, Frauenglass S, Routh D, Pantin H, and Mason, C (1997). Family support decreases influence of deviant peers on hispanic adolescents'substance use. J Clin Child Psychol 26, 15-23.

Grace R.C, Nevin J.A. On the relation between preference and resistance to change. Journal of the Experimental Analysis of Behavior. 1997;67:43-65

Groh DR, Jason LA, and Keys CB. (2008) Social network variables in alcoholics anonymous: a literature review. Clin. Psychol 28: 430-450.

Hall, F. S., Huang, S., Fong, G. W., Pert, A., \& Linnoila, N. (1998). Effects of isolationrearing on locomotion, anxiety and responses to ethanol in Fawn Hooded and Wistar rats. Psychopharmacology, 139(3), 203-209. http://doi.org/10.1007/s002130050705

Harmer, C. J., \& Phillips, G. D. (1998). Isolation rearing enhances the rate of acquisition of a discriminative approach task but does not affect the efficacy of a conditioned reward. Physiology and Behavior, 63(2), 177-184. http://doi.org/10.1016/S00319384(97)00417-4

Heyman, G. M.: Preference for saccharin sweetened alcohol relative to isocaloric sucrose. Psychopharmacology (Berlin) 129:72-78; 1997. http://digitalcommons.usu.edu/etd/124

Hursh SR, Silberberg A (2008) Economic demand and essential value. Psychological Review 115(1):186-198 
Hyman, S. E., Malenka, R. C., \& Nestler, E. J. (2006). Neural mechanisms of addiction: the role of reward-related learning and memory. Annual Review of Neuroscience, 29, 565598. http://doi.org/10.1146/annurev.neuro.29.051605.113009

Jimenez-Gomez, C., \& Shahan, T. A. (2007). Resistance to change of alcohol selfadministration: effects of alcohol-delivery rate on disruption by extinction and naltrexone. Behavioral Pharmacology, 18(2), 161-169. doi:

10.1097/FBP.0b013e3280f2756f

Jimenez-Gomez, C., \& Shahan, T. A. (2008). Matching law analysis of rats alcohol selfadministration in a free operant choice procedure. Behavioural Pharmacology, 19, 353-356.

Kennedy, B. C., Panksepp, J. B., Runckel, P. A., \& Lahvis, G. P. (2012). Social influences on morphine-conditioned place preference in adolescent BALB/cJ and C57BL/6J mice. Psychopharmacology, 219(3), 923-932. http://doi.org/10.1007/s00213-011$2421-2$

Lankford, M. F., Roscoe, A. K., Pennington, S. N., and Myers, R. D. (1991). Drinking of high concentrations of ethanol versus palatable fluids in alcohol-preferring $(\mathrm{P})$ rats: Valid animal model of alcoholism. Alcohol 8:293-299.

Lesscher, H. M. B., Spoelder, M., Rotte, M. D., Janssen, M. J., Hesseling, P., Lozemanvan’t Klooster, J. G., ... Vanderschuren, L. J. M. J. (2015). Early social isolation augments alcohol consumption in rats. Behavioural Pharmacology, $26(7 \mathrm{Spec} \mathrm{No})$, 673-80. http://doi.org/10.1097/FBP.0000000000000165 
Lodge D.J., Lawrence A.J. (2003) The effect of isolation rearing on volitional ethanol consumption and central CCK/dopamine systems in Fawn-Hooded rats. Behavioral Brain Research 141:113-122

Maccioni, P., Orru, A., Korkosz, A., Gessa, G. L., Carai, M. A., Colombo, G., \& Bienkowski, P. (2007). Cue-induced reinstatement of ethanol seeking in Sardinian alcohol-preferring rats. Alcohol, 41(1), 31-39. doi: 10.1016/j.alcohol.2007.02.006

McCool, B. A., \& Chappell, A. M. (2009). Early social isolation in male Long-Evans rats alters both appetitive and consummatory behaviors expressed during operant ethanol self-administration. Alcohol: Clinical Experimental Research, 33(2), 273282. doi: 10.1111/j.1530-0277.2008.00830.x

Nash JF, Maickel RP (1985). Stress-induced consumption of ethanol by rats. Life Sciences. 37:757-765.

Nevin J.A. Measuring behavioral momentum. Behavioural Processes. 2002;57:187-198.

Nevin J.A., Grace R.C. Behavioral momentum and the law of effect. Behavioral and Brain Sciences. 2000;23:73-130.

Nevin J.A., Tota M.E., Torquato RD, Shull RL. Alternative reinforcement increases resistance to change: Pavlovian or operant contingencies? Journal of Experimental Analysis of Behavior. 1990;53:359-379.

Nevin, J. A. (1992). An integrative model for the study of behavioral momentum. Journal of the Experimental Analysis of Behavior, 57, 301-316.

Nevin, J. A. Response strength in multiple schedules. Journal of the Experimental Analysis 
of Behavior, 1974, 21, 389-409.

Nevin, J. A., \& Shahan, T. A. (2011). Behavioral momentum theory: Equations and applications. Journal of Applied Behavior Analysis. 44, 877-895.

Parker, L.F. and Radow, B.L. (1974). Isolation stress and volitional ethanol consumption in the rat. Physiology and Behavior, 12, 1-3.

Podlesnik, C. A., Jimenez-Gomez, C., \& Shahan, T. A. (2013). Are preference and resistance to change convergent expressions of stimulus value? Journal of Experimental Analysis of Behavior, 100(1), 27-48. doi: 10.1002/jeab.33

Quick, S. L., \& Shahan, T. A. (2009). Behavioral momentum of cocaine selfadministration: effects of frequency of reinforcement on resistance to extinction. Behavioral Pharmacology, 20(4), 337-345. doi: 10.1097/FBP.0b013e32832f01a8

Schultz, W. (2010). Dopamine signals for reward value and risk: basic and recent data. Behavioral and Brain Functions : BBF, 6, 24. http://doi.org/10.1186/1744-9081-6-24

Schultz, W. (2013). Updating dopamine reward signals. Current Opinion in Neurobiology. http://doi.org/10.1016/j.conb.2012.11.012

Sharpe, A. L., \& Samson, H. H. (2001). Effect of naloxone on appetitive and consummatory phases of ethanol self-administration. Alcoholism, Clinical and Experimental Research, 25(7), 1006-1011.

Van Den Berg, C. L., Pijlman, F. T. A., Koning, H. A. M., Diergaarde, L., Van Ree, J. M., \& Spruijt, B. M. (1999). Isolation changes the incentive value of sucrose and social 
behaviour in juvenile and adult rats. Behavioural Brain Research, 106(1-2), 133-142. http://doi.org/10.1016/S0166-4328(99)00099-6

Weiss, F., Martin-Fardon, R., Ciccocioppo, R., Kerr, T. M., Smith, D. L., \& Ben-Shahar, O. (2001). Enduring Resistance to Extinction of Cocaine-Seeking Behavior Induced by Drug-Related Cues. Neuropsychopharmacology, 25(3), 361-372.

Araujo, N. P., Camarini, R., Souza-Formigoni, M. L. O., Carvalho, R. C., Abílio, V. C., Silva, R. H., ... Frussa-Filho, R. (2005). The importance of housing conditions on behavioral sensitization and tolerance to ethanol. Pharmacology Biochemistry and Behavior, 82(1), 40-45. http://doi.org/10.1016/j.pbb.2005.07.009

Bachmanov, A. A., Kiefer, S. W., Molina, J. C., Tordoff, M. G., Duffy, V. B., Bartoshuk, L. M., \& Mennella, J. A. (2003). Chemosensory factors influencing alcohol perception, preferences, and consumption. Alcoholism, Clinical and Experimental Research, 27(2), 220-31. http://doi.org/10.1097/01.ALC.0000051021.99641.19

Beardsley, P. M., Lemaire, G. A., \& Meisch, R. A. (1993). Persistence of ethanol selfadministration as a function of interreinforcer interval and concentration. Drug and Alcohol Dependence, 34(1), 71-81. Retrieved from http://www.ncbi.nlm.nih.gov/pubmed/8174504

Bienkowski, P., Koros, E., Kostowski, W., \& Bogucka-Bonikowska, A. (2000). Reinstatement of ethanol seeking in rats: behavioral analysis. Pharmacol Biochem Behav, 66(1), 123-128. Journal Article. Retrieved from http://www.ncbi.nlm.nih.gov/pubmed/10837851

Bienkowski, P., Kostowski, W., \& Koros, E. (1999). The role of drug-paired stimuli in extinction and reinstatement of ethanol-seeking behaviour in the rat. European 
Journal of Pharmacology, 374(3), 315-319. Journal Article.

http://doi.org/http://dx.doi.org/10.1016/S0014-2999(99)00244-7

Cortés-Patiño, D. M., Serrano, C., \& Garcia-Mijares, M. (2016). Early social isolation increases persistence of alcohol-seeking behavior in alcohol-related contexts.

Behavioural Pharmacology, 27(2-3 Spec Issue), 185-91.

http://doi.org/10.1097/FBP.0000000000000213

Deehan, G. A., Cain, M. E., \& Kiefer, S. W. (2007). Differential rearing conditions alter operant responding for ethanol in outbred rats. Alcoholism: Clinical and Experimental Research, 31(10), 1692-1698. http://doi.org/10.1111/j.1530-0277.2007.00466.x

Deehan, G. A., Palmatier, M. I., Cain, M. E., \& Kiefer, S. W. (2011a). Differential rearing conditions and alcohol-preferring rats: consumption of and operant responding for ethanol. Behavioral Neuroscience, 125(2), 184-193. http://doi.org/10.1037/a0022627

Deehan, G. A., Palmatier, M. I., Cain, M. E., \& Kiefer, S. W. (2011b). Differential rearing conditions and alcohol-preferring rats: consumption of and operant responding for ethanol. Behavioral Neuroscience, 125(2), 184-93. http://doi.org/10.1037/a0022627

Elmer, G. I., Meisch, R. A., \& George, F. R. (1987). Differential concentration-response curves for oral ethanol self-administration in $\mathrm{C} 57 \mathrm{BL} / 6 \mathrm{~J}$ and BALB/cJ mice. Alcohol, 4(1), 63-68. http://doi.org/10.1016/0741-8329(87)90062-0

Everitt, B. J., Belin, D., Economidou, D., Pelloux, Y., Dalley, J. W., \& Robbins, T. W. (2008). Review. Neural mechanisms underlying the vulnerability to develop compulsive drug-seeking habits and addiction. Philosophical Transactions of the Royal Society of London. Series B, Biological Sciences, 363(1507), 3125-3135. http://doi.org/10.1098/rstb.2008.0089

Hall, F. S., Huang, S., Fong, G. W., Pert, A., \& Linnoila, M. (1998a). Effects of isolation- 
rearing on voluntary consumption of ethanol, sucrose and saccharin solutions in Fawn Hooded and Wistar rats. Psychopharmacology, 139(3), 210-6. Retrieved from http://www.ncbi.nlm.nih.gov/pubmed/9784075

Hall, F. S., Huang, S., Fong, G. W., Pert, A., \& Linnoila, N. (1998b). Effects of isolationrearing on locomotion, anxiety and responses to ethanol in Fawn Hooded and Wistar rats. Psychopharmacology, 139(3), 203-209. http://doi.org/10.1007/s002130050705

Harmer, C. J., \& Phillips, G. D. (1998). Isolation rearing enhances acquisition in a conditioned inhibition paradigm. Physiology and Behavior, 65(3), 525-533. http://doi.org/10.1016/S0031-9384(98)00207-8

Harmer, C. J., \& Phillips, G. D. (1998). Isolation rearing enhances the rate of acquisition of a discriminative approach task but does not affect the efficacy of a conditioned reward. Physiology and Behavior, 63(2), 177-184. http://doi.org/10.1016/S00319384(97)00417-4

Harmer, C. J., \& Phillips, G. D. (1998). Isolation Rearing Enhances the Rate of Acquisition of a Discriminative Approach Task but Does Not Affect the Efficacy of a Conditioned Reward. Physiology \& Behavior, 63(2), 177-184. http://doi.org/10.1016/S00319384(97)00417-4

Hyman, S. E., Malenka, R. C., \& Nestler, E. J. (2006). Neural mechanisms of addiction: the role of reward-related learning and memory. Annual Review of Neuroscience, 29, 565598. http://doi.org/10.1146/annurev.neuro.29.051605.113009

Jimenez-Gomez, C., \& Shahan, T. A. (2007). Resistance to change of alcohol selfadministration: effects of alcohol-delivery rate on disruption by extinction and naltrexone. Behavioural Pharmacology, 18(2), 161-9. http://doi.org/10.1097/FBP.0b013e3280f2756f 
Kennedy, B. C., Panksepp, J. B., Runckel, P. A., \& Lahvis, G. P. (2012). Social influences on morphine-conditioned place preference in adolescent BALB/cJ and C57BL/6J mice. Psychopharmacology, 219(3), 923-932. http://doi.org/10.1007/s00213-011$2421-2$

Maccioni, P., Orrú, A., Korkosz, A., Gessa, G. L., Carai, M. A. M., Colombo, G., \& Bienkowski, P. (2007). Cue-induced reinstatement of ethanol seeking in Sardinian alcohol-preferring rats. Alcohol (Fayetteville, N.Y.), 41(1), 31-9. http://doi.org/10.1016/j.alcohol.2007.02.006

Martinetti, M. P., Khan, Z., \& Lewis, M. J. (2007). Matching law choice analyses of ethanol and sucrose consumption in alcohol-preferring $(\mathrm{P})$, nonpreferring $(\mathrm{NP})$, and Sprague-Dawley (SD) rats. Alcoholism, Clinical and Experimental Research, 31(8), 1338-48. http://doi.org/10.1111/j.1530-0277.2007.00428.x

McCool, B. A., \& Chappell, A. M. (2009). Early social isolation in male long-evans rats alters both appetitive and consummatory behaviors expressed during operant ethanol self-administration. Alcoholism: Clinical and Experimental Research, 33(2), 273-282. http://doi.org/10.1111/j.1530-0277.2008.00830.x

Meisch, R. A., \& Thompson, T. (1974). Ethanol intake as a function of concentration during food deprivation and satiation. Pharmacology Biochemistry and Behavior, 2(5), 589-596. http://doi.org/10.1016/0091-3057(74)90025-2

Nevin, J. A., \& Grace, R. C. (2000). Behavioral momentum and the Law of Effect. Behavioral and Brain Sciences, 23(1), 73-90. http://doi.org/10.1017/S0140525X00002405

Phillips, G. D., Harmer, C. J., \& Hitchcott, P. K. (2002). Isolation rearing-induced facilitation of Pavlovian learning: Abolition by postsession intra-amygdala 
nafadotride. Physiology and Behavior, 76(4-5), 677-684.

http://doi.org/10.1016/S0031-9384(02)00802-8

Podlesnik, C. A., Jimenez-Gomez, C., \& Shahan, T. A. (2013). Are preference and resistance to change convergent expressions of stimulus value? Journal of the Experimental Analysis of Behavior, 100(1), 27-48. http://doi.org/10.1002/jeab.33

Pyszczynski, A. D., \& Shahan, T. A. (2011). Behavioral momentum and relapse of ethanol seeking: nondrug reinforcement in a context increases relative reinstatement. Behavioural Pharmacology, 22(1), 81-6. http://doi.org/10.1097/FBP.0b013e328341e9fb

Richardson, N. R., \& Roberts, D. C. S. (1996). Progressive ratio schedules in drug selfadministration studies in rats: a method to evaluate reinforcing efficacy. Journal of Neuroscience Methods, 66(1), 1-11. http://doi.org/10.1016/0165-0270(95)00153-0

Rockman, G.E., Gibson, J.E. y Benarroch, A. (1989). Effects of environmental enrichment on voluntary ethanol intake in rats. Pharmacology Biochemistry and Behavior, 34, $487-490$.

Samson HH, Slawecki CJ, Sharpe AL, Chappell A (1998) Appetitive and consummatory behaviors in the control of ethanol consumption: A measure of ethanol seeking behavior. Alcohol Clin Exp Res 22:1783-1787.

Samson, H. H., Files, F. J., Denning, C., and Marvin, S. (1998). Comparison of alcoholpreferring and nonpreferring selectively bred rat lines. I. Ethanol initiation and limited access operant selfadministration. Alcohol. Clin. Exp. Res. 22:2133-2146. 
Samson, H. H., Pfeffer, A. O., \& Tolliver, G. (1988). Oral ethanol self-administration in rat: Models of alcohol-seeking behavior. Alcoholism: Clinical and Experimental Research, 12, 591-598.

Shahan TA (2002). The observing-response procedure: a novel method to study drugassociated conditioned reinforcement. Experimental and Clinical Psychopharmacology 10:3-9.

Shahan TA, Burke KA (2004). Ethanol-maintained responding of rats is more resistant to change in a context with added non-drug reinforcement. Behav Pharmacol,15:279285

Shahan, T. A., \& Jimenez-Gomez, C. (2006). Effects of self-administered alcohol concentration on the frequency and persistence of rats' attending to alcohol cues. Behavioural Pharmacology, 17(3), 201-11. Retrieved from http://www.ncbi.nlm.nih.gov/pubmed/16571998

Shahan, T. A., \& Jimenez-Gomez, C. (2006). Effects of self-administered alcohol concentration on the frequency and persistence of rats' attending to alcohol cues. Behavioural Pharmacology, 17(3), 201-11. Retrieved from http://www.ncbi.nlm.nih.gov/pubmed/16571998

Schenk, S., Gorman, K., e Amit. Z (1990). Age-dependent effects of isolation housing on the self-administration of ethanol in laboratory rats. Alcohol, 7, 321-326.

Schenk, S., Gorman, K., e Amit. Z (1990). Age-dependent effects of isolation housing on the self-administration of ethanol in laboratory rats. Alcohol, 7, 321-326.

Schultz, W. (2010). Dopamine signals for reward value and risk: basic and recent data. 
Behavioral and Brain Functions : BBF, 6, 24. http://doi.org/10.1186/1744-9081-6-24

Schultz, W. (2013). Updating dopamine reward signals. Current Opinion in Neurobiology. http://doi.org/10.1016/j.conb.2012.11.012

Slawecki, C. J., \& Samson, H. H. (1997). Changes in Oral Ethanol Self-Administration Patterns Resulting from Ethanol Concentration Manipulations. Alcoholism: Clinical and Experimental Research, 21(6), 1144-1149. http://doi.org/10.1111/j.15300277.1997.tb04265.x

Van Den Berg, C. L., Pijlman, F. T. A., Koning, H. A. M., Diergaarde, L., Van Ree, J. M., \& Spruijt, B. M. (1999). Isolation changes the incentive value of sucrose and social behaviour in juvenile and adult rats. Behavioural Brain Research, 106(1-2), 133-142. http://doi.org/10.1016/S0166-4328(99)00099-6

Whitaker, L. R., Degoulet, M., \& Morikawa, H. (2013a). Social Deprivation Enhances VTA Synaptic Plasticity and Drug-Induced Contextual Learning. Neuron, 77(2), 335345. http://doi.org/10.1016/j.neuron.2012.11.022

Whitaker, L. R., Degoulet, M., \& Morikawa, H. (2013b). Social deprivation enhances VTA synaptic plasticity and drug-induced contextual learning. Neuron, 77(2), 335-45. http://doi.org/10.1016/j.neuron.2012.11.022

Wolffgramm, J., \& Heyne, A. (1991). Social behavior, dominance, and social deprivation of rats determine drug choice. Pharmacology, Biochemistry, and Behavior, 38(2), 389-99. Retrieved from http://www.ncbi.nlm.nih.gov/pubmed/2057508

Wolffgramm, J., \& Heyne, A. (1995). From controlled drug intake to loss of control: The irreversible development of drug addiction in the rat. In Behavioural Brain Research (Vol. 70, pp. 77-94). http://doi.org/10.1016/0166-4328(95)00131-C 
Zakharova, E., Miller, J., Unterwald, E., Wade, D., \& Izenwasser, S. (2009). Social and physical environment alter cocaine conditioned place preference and dopaminergic markers in adolescent male rats. Neuroscience, 163(3), 890-897.

http://doi.org/10.1016/j.neuroscience.2009.06.068 